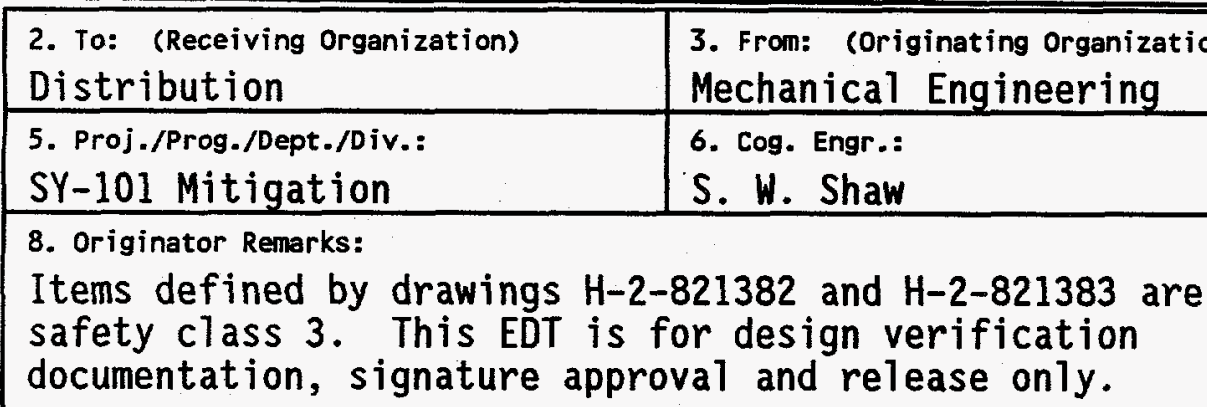

11. Receiver Remarks:

\section{Page 1 of 1. EDT 607556}

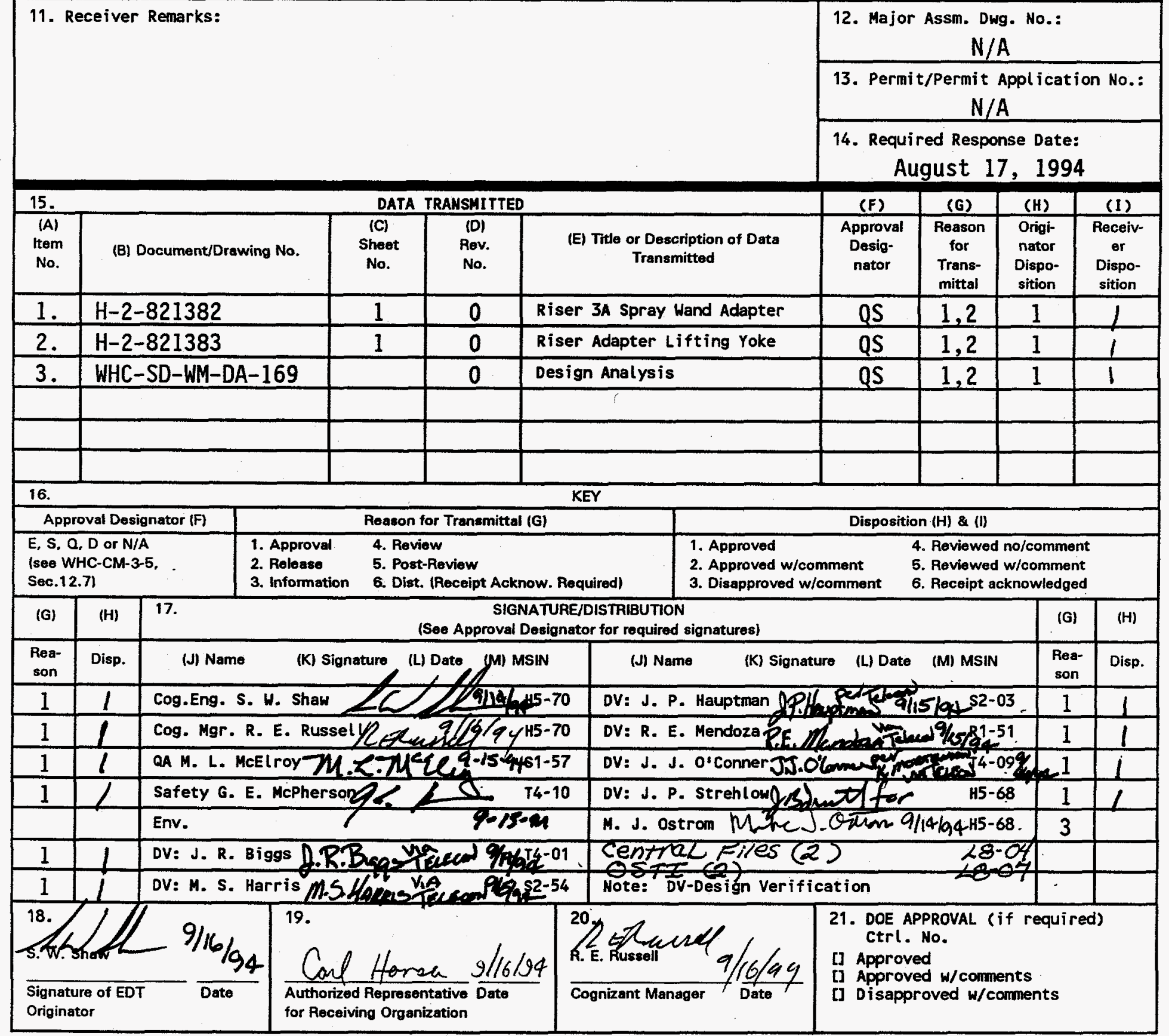

BD-7400-172-2 (04/94) GEF097 


\section{DISCLAIMER}

Portions of this document may be illegible in electronic image products. Images are produced from the best available original document. 


\section{RELEASE AUTHORIZATION}

Document Number: WHC-SD-WM-DA-169, REV. 0

Document Title: $\quad$ Design Analysis Supporting 101-SY Riser 3A Spraywand Adapter and Lifting Yoke Design

Release Date: $\quad 9 / 16 / 94$

This document was reviewed following the procedures described in WHC-CM-3-4 and is:

APPROVED FOR PUBLIC RELEASE

**************

WHC Information Release Administration Specialist:

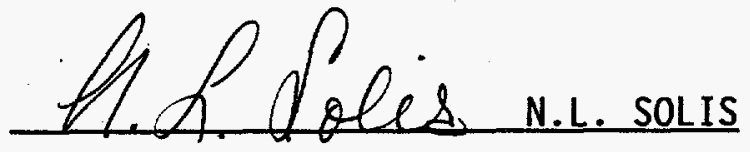

(Signature)

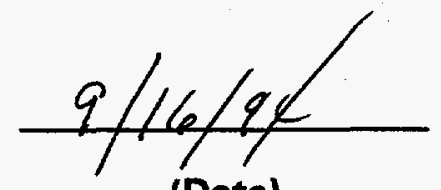

(Date) 
2. Title

Design Analysis Supporting 101-SY Riser 3A Spraywand Adapter and Lifting Yoke Design

5. Key Words

Adapter, Lifting, Yoke, Spraywand, 101-SY

APPROVED FOR

PIBIICPELEASE
0
4. Rev No.

WHC-SD-WM-DA-169

6. Author

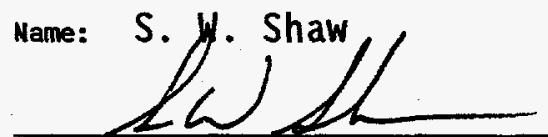

signature

7. Abstract $9 / 16 / 940$. Joli

Organization/Charge code 8D320/N2B6f

This document contains the results of stress and radiological analysis performed in support of the Riser 3A Spraywand Adapter and Lifting Yoke.

8. PURRPSE AND USE OF DOCYMENT - This docitent was prep/red for use with the U.S. Departo int of Energy and is contract's. It is to be und only to frform, direct, or integray work under U.S. DE,artment of E ergy contracts. This c cument is not approved for publ release intil reviewed.

PATENT STATL - This document copy, since it is transmitted in advance of pat clearance, is made available in confidence solely for use in p rformance of work under con acts with the U.S. Departme ti of Energy. This document is bt to published nor its content otherw se disseminated or used for purp ses other than specified bove befor patent approval for such relec $e$ or use has been secy ed, upon requ $t$, from the Pater, Counsel, U.S. Department of Ener/f Field Office, Richland, WA.

$\checkmark$.

DISCLAIMER - This report was prepared as an account of work sponsored by an agency of the United States Government. Neither the United States Government nor any agency thereof, nor any of their employees, nor any of their contractors, subcontractors or their employees, makes any warranty, express or implied, or assumes any legal liability or responsibility for the accuracy, completeness, or any third party's use or the results of such use of any information, apparatus, product, or process disclosed, or represents that its use would not infringe privately owned rights. Reference herein to any specific commercial product, process, or service by trade name, trademark, manufacturer, or otherwise, does not necessarily constitute or imply its endorsement, recommendation, or favoring by the United States Government or any agency thereof or its contractors or subcontractors. The views and opinions of authors expressed herein do not necessarily state or reflect those of the United States Government or any agency thereof.

10.

RELEASE STAMP

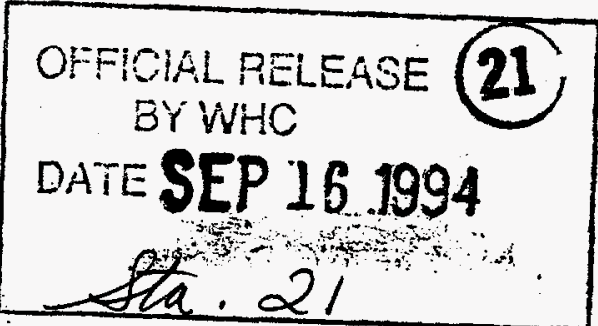

9. Impact Level $Q, S$

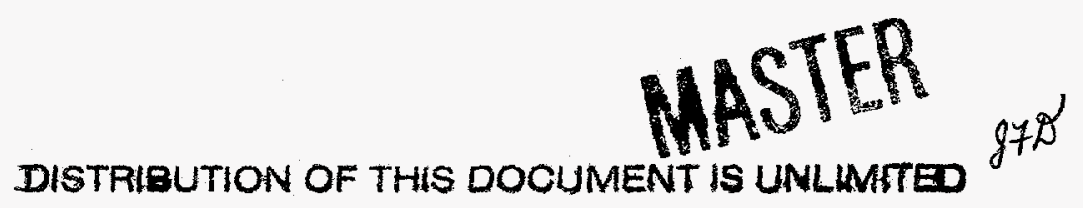




\title{
DESIGN ANALYSIS SUPPORTING 101-SY \\ RISER 3A SPRAYWAND ADAPTER \\ AND LIFTING YOKE DESIGN
}

\author{
WHC-SD-WM-DA-169 \\ REV 0 \\ September 12, 1994 \\ by
}

S. W. Shaw

Mechanical Engineering 


\section{TABLE OF CONTENTS}

1.0 INTRODUCTION . . . . . . . . . . . . . . . . . . . . 1

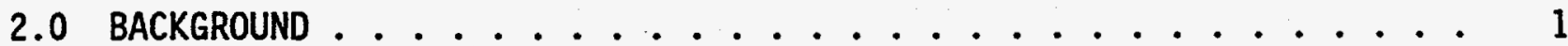

3.0 RESULTS . •

3.1 RADIOLOGICAL . . . . . . . . . . . . . . . . . 1

3.2 STRESS ........................ 1 
WHC-SD-WM-DA-169

Rev 0

Page 1.

\subsection{INTRODUCTION}

To facilitate the decontamination of mixing pumps installed in riser $12 \mathrm{~A}$ of double shell waste tank 241-SY-101, it was determined that installation of a spraywand (H-2-817857) in riser $3 A$ would be desireable. This document is to record the results of analysis performed in support of the spraywand riser adapter (H-2-821382) and lifting yoke (H-2-821383) designs.

\subsection{BACKGROUND}

Considerations pertinant to a spraywand installation in riser $3 \mathrm{~A}$ included establishing spraywand elevation in the pump pit, provision of shielding to minimize radiation exposure to workers in the vicinity, and a methodology for installation which was well defined.

\subsection{RESULTS}

\subsection{RADIOLOGICAL}

The results of shielding analysis performed to determine dose rates in the vicinity of the riser adapter are shown in Attachment $A$.

\subsection{STRESS}

The results of stress analysis supporting the design of the riser adapter and lifting yoke are shown in Attachment B. 
WHC-SD-WM-DA-169

Rev 0

Page A-1

ATTACHMENT A

RADIOLOGICAL ANALYSIS 
From: Radiation Physics and Shielding

80530-KEH-94-001

Phone: : 376-1889 HO-35

Date: August 17, 1994

Subject: DOSE RATE CALCULATIONS IN THE VICINITY OF THE SPRAY WAND IN TANK 101-SY

To:

S. W. Shaw

H5-70

cc:

J. Greenborg

HO-35

R. A. Schwarz

KEH File/LB

HO- 35

References: 1. L. L. Carter, Certification of MCNP Version 4A for the WHC Computer Platforms, ECN-186710, SD-MP-SWD-30001, Rev. 6, January 1994.

2. Memo, Brit E. Hey to T. R. Benegas, Dose Rate Calculations in Vicinity of Waste Tank 101-SY Mixer Pump and Shield Plug, dated September 1, 1992.

3. Memo, R. A. Schwarz and K. E. Hillesland to

D. R. Precechtel, Dose Rate Calculations for Installing a Multi-Port Riser on Tank SY-101, dated February 24, 1994.

4. Israel 0. Lourant, Validation of ISOSHLD-PC on the IBM PC (PS-2/AT/XT). EDT-109878, WHC-SD-SQA-CSWD-303, Rev. 0, 0, February 1990.

\subsection{SUMMARY}

Dose Rates have been calculated in the vicinity of a spray wand placed in tank 101-SY using MCNP (Reference 1). Figure 1 is a contour plot showing dose rates in the pump pit. The dose rate at the top of the shielding assembly is about $200 \mathrm{mrem} / \mathrm{hr}$. Notice that the model dose not include the spray wand, drill rod washer, and 12 in. flange. The model also uses plugs in the 42 in. and 4 in. risers inside the pump pit to simplify the analysis, since the focus is the $12 \mathrm{in.}$ riser.

\subsection{GEOMETRY}

The model was developed from a previous MCNP model created by Brit Hey (Reference 2). The spray wand shielding was placed on the 12 in. riser inside the pump pit. The shield consisted of a 3 in. cover plate, and an axial shield. The axial shield is made from filling the annulus between 6 in. schedule 40 and 14 in. schedule 40 pipe with steel shot. The top of the 
WHC-SD-WM-DA-169

REV 0

Page A-3

S. W. Shaw

8D530-KEH-94-001

Page 2

August 17, 1994

shielding assembly is 65.55 in. above the bottom of the pump pit. The steel was modeled as $7.8 \mathrm{~g} / \mathrm{cc}$ iron, and the steel shot as $4.68 \mathrm{~g} / \mathrm{cc}$ iron. For simplicity, the $42 \mathrm{in}$. and 6 in. risers were modeled with concrete plugs in place.

The top of the supernate was put at 400 in. above the bottom of the tank. The composition of the supernate was also taken from a previous MCNP model (Reference 2), but with a density of $1.55 \mathrm{~g} / \mathrm{cc}$. The density for the supernate was based on a homogeneous mixture with sludge (Reference 3 ).

\subsection{SOURCE}

The source consisted of a $160 \mathrm{~cm}$ radius, $60 \mathrm{~cm}$ deep cylinder at the top of 10I-SY's supernate and centered beneath the 12 in. riser. A $1.277 E+14 \mathrm{~Bq}$ $(1.764 E+7 \mathrm{~Bq} / \mathrm{CC}$ ) source at an energy of $.662 \mathrm{MeV}$ was used (Reference 3 "homogenized source"). The choice of $.662 \mathrm{MeV}$ is based on the assumption that $\mathrm{Cs}-137 / \mathrm{Ba}-137 \mathrm{~m}$ is the dominant source for photons.

\subsection{MCNP OPTIMIZATION :}

The source was split into three radial and three axial sections for a total of nine cells in order to bias towards the top and center of the source. A DXTRAN sphere was placed at the bottom of the 12 in. riser.

\subsection{RESULTS}

Figure 1 is a contour plot showing dose rates in the pump pit. The dose rate at the top of the shielding assembly is about $200 \mathrm{mrem} / \mathrm{hr}$ due to streaming directly up through the 6 in. pipe. To the sides, dose rates are generaliy less than $1 \mathrm{mrem} / \mathrm{hr}$. Near the 3 in. plates, dose rates are as high as $12 \mathrm{mrem} / \mathrm{hr}$.

The dose rates in the pit are based on the assumption that the 42 in. and 4 in. risers have their concrete plugs in place. Because the model concentrated on streaming through the $12 \mathrm{in.} \mathrm{riser,} \mathrm{dose} \mathrm{rates} \mathrm{due} \mathrm{to}$ penetration of the $4 \mathrm{in}$. plug are good to within an order of magnitude (20 to 40 percent variance), and dose rates due to penetration of the 42 in. plug are unreliable to the sides. (50+ percent variance). Any additional dose rates in the pump pit from different configurations for these risers are additive to those reported here.

\subsection{VERIFICATION}

A second MCNP run was made with a surface tally at the top of the shielding assembly. This result was compared to an ISO-PC (Ver 1.9) (Reference 4) run. 
S. W. Shaw

August 17, 1994

\subsection{ARCHIVAL FILES}

The archival files are stored on a 3.5 in. disk labelled "Karl Hillesland 7/94" under the directory wand. The files include the following:
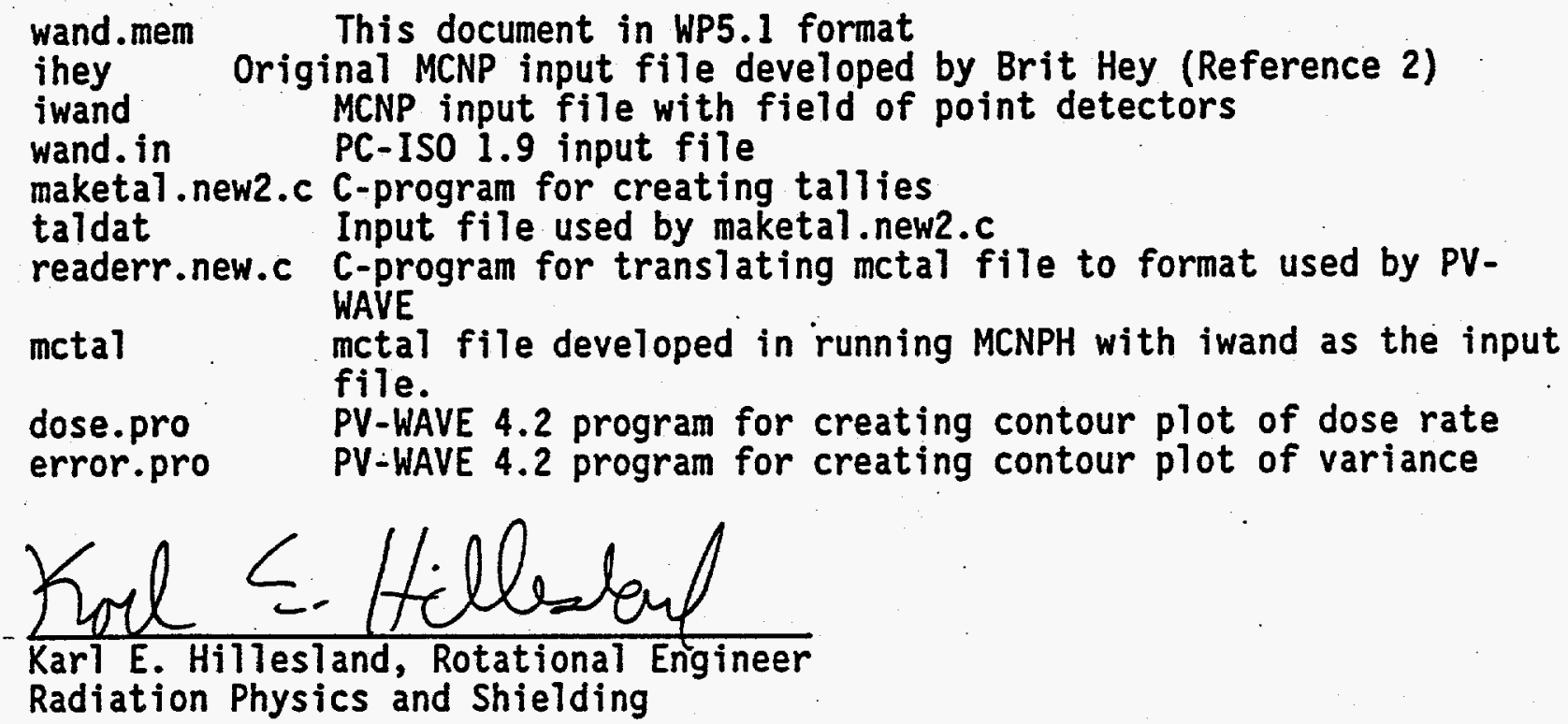

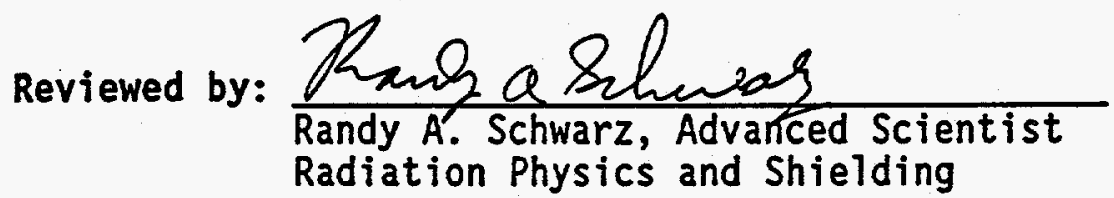

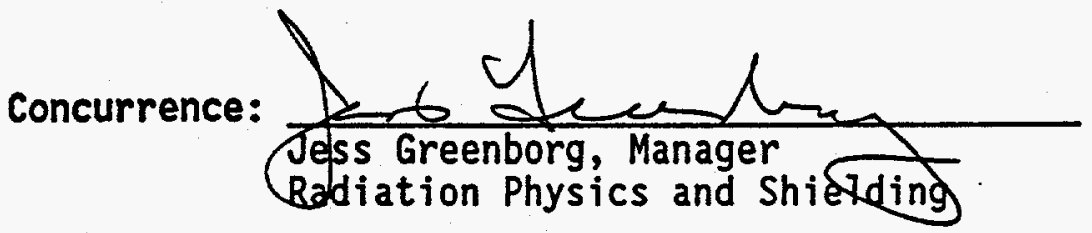

sam

Attachments 
WHC-SD-WM-DA-169

REV 0

Page A-5

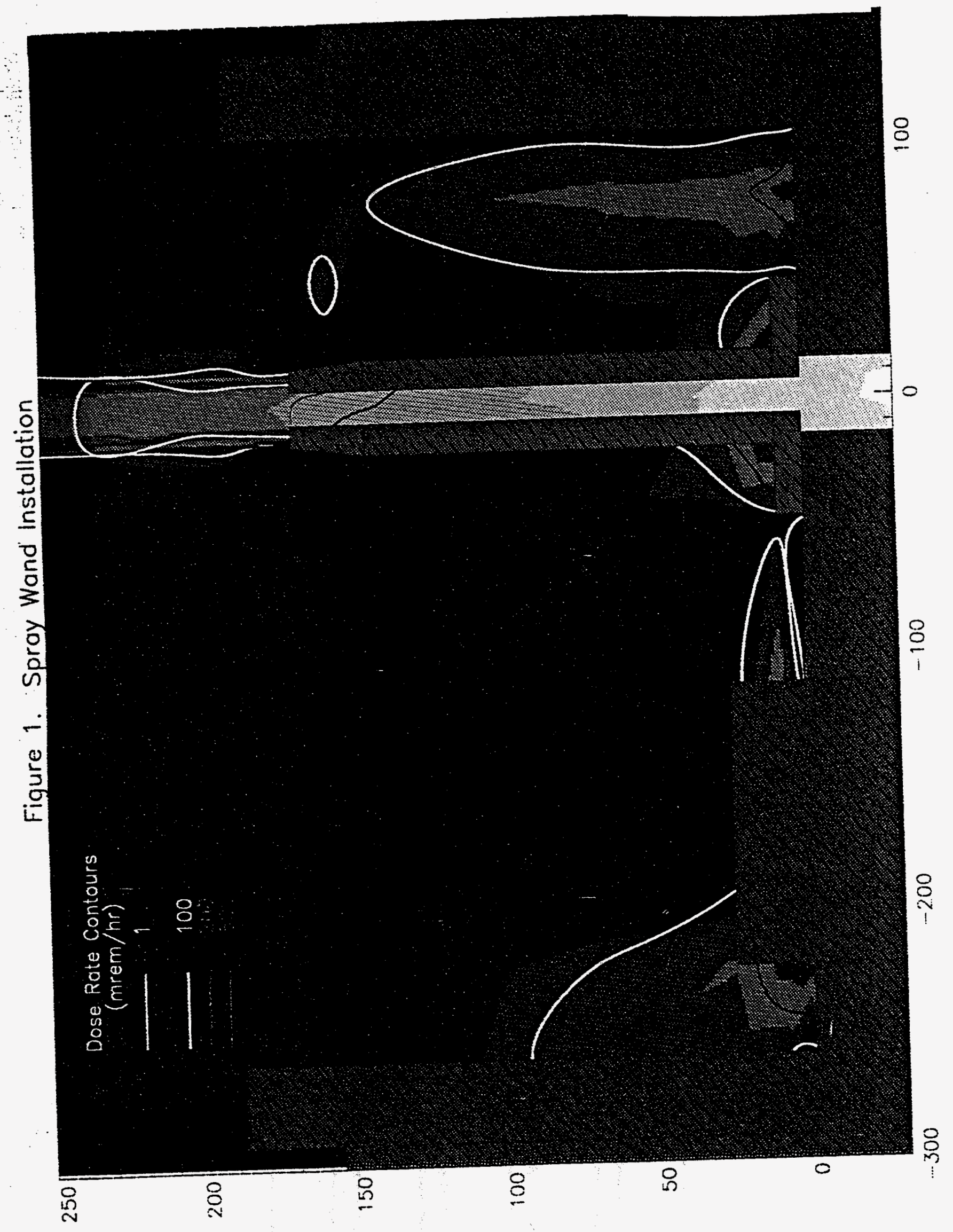


WHC-SD-WM-DA-169

Rev 0

Page B-1

ATTACHMENT B

STRESS ANALYSIS 
From: Mechanical Engineering

Phone: $\quad 376-3244$ H5-70

Date: July 26, 1994

Subject: STRUCTURAL ANLAYSIS OF RISER 3A SPRAY WAND ADAPTER

To: S. W. Shaw H5-70

CC: DAK-File/LB

References: DOE-RL, 1993, Hanford Site Hoisting and Rigging Manual, DOE-RL $92-36$, U.S. Department of Energy, Richl and Operations office, Richland, Washington.

Pytel, A., and F. L. Singer, 1987, Strength of Materials, Fourth Edition, Harper and Row, Publishers, New York, New York.

WHC, 1994a, Riser $3 A$ Spray Wand Adapter, drawing H-2-821382, Westinghouse Hanford Company, Richland, Washington.

WHC, 1994b, Riser Adapter Lifting Yoke, drawing H-2-821383, Westinghouse Hanford Company, Richland, Washington.

The riser $3 A$ spray wand adapter (drawing $H-2-821382$ ) and lifting yoke (drawing H-2-821383) were structurally analyzed for lifting and found acceptable per criteria given in the Hanford Site Hoisting and Rigging Manual. The rigging manual states that maximum stress shall not exceed one-third of the minimum yield strength of the material.

The weight of the spray wand adapter is estimated at 3,382 lbf including the shield cap. This weight is an upper bound to the actual weight, which will be significantly less. The shield cap weighs considerably more than the drill rod washer, so it was included in the weight estimate instead of the washer. The steel shot cavity was assumed solid, conservatively increasing the estimated weight of the adapter.

For design purposes, the weight of the adapter was assumed to be 3,500 lbf. A dynamic load factor (DLF) of 2.0 was assumed for conservatism. The structural analysis focused principally on the lifting lugs of the adapter and spreader bar (lifting yoke). The lugs were analyzed for tensile and bending failure, shear tear out, and adequacy of connecting welds. The critical welds of the adapter assembly al so were evaluated and found acceptable. 
S. W. Shaw

Page 2

July 26, 1994
WHC-SD-WM-DA-169

REV 0

Page B-3

All questions regarding the attached analysis should be directed to

D. A. Koehler at 376-3244.

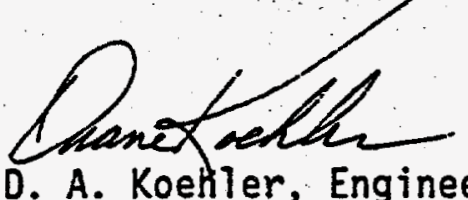

D. A. Koehter, Engineer

Mechanical Engineering

$\backslash \mathrm{kph}$

Attachment 
WHC-SD-WM-DA-169

REV 0

Page B-4

Riser 3A Spray Wand Adapter Stress Analysis

\section{JuTy 1994}

Prepared By:

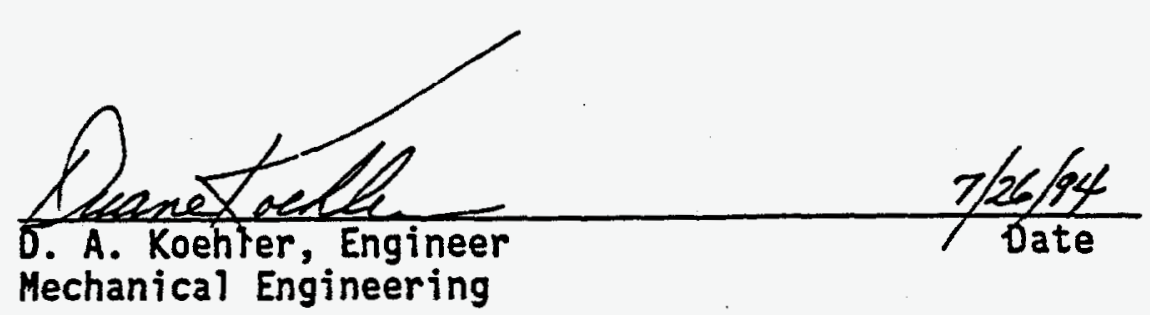

Reviewed By:

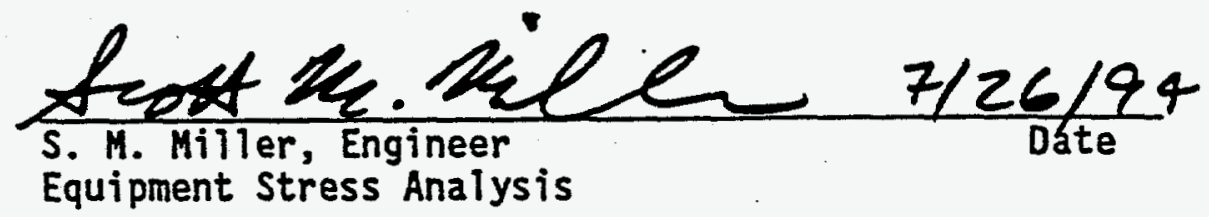

Approved By:

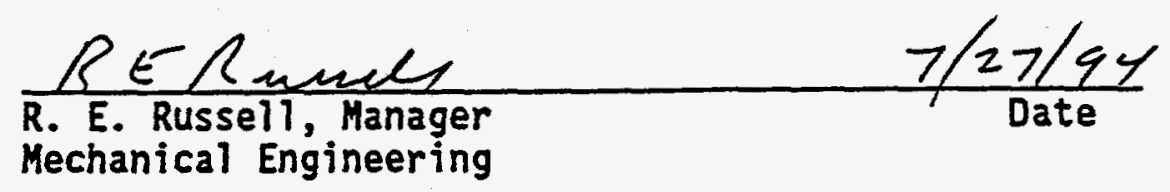

WESTINGHOUSE HANFORD COMPANY

for the

U.S. Department of Energy

Richland Field office (RL) 
WHC-SD-WM-DA-169

REV 0

Page B-5

\section{INDEPENDENT REVIEW}

Document Reviewed Riser $3 A$ Spray Wand Adapter Stress Analysis

Author D.A. Koehler Document No.

EDT No.

The subject document has been reviewed by the undersigned. The reviewer reviewed and verified the following items as applicable [EP.4.1, Rev. 3].

- Engineering Specification

- Design Input

- Basic Assumption

- Approach/Design Methodology

- Related Information

- Conclusion/Result Interpretation
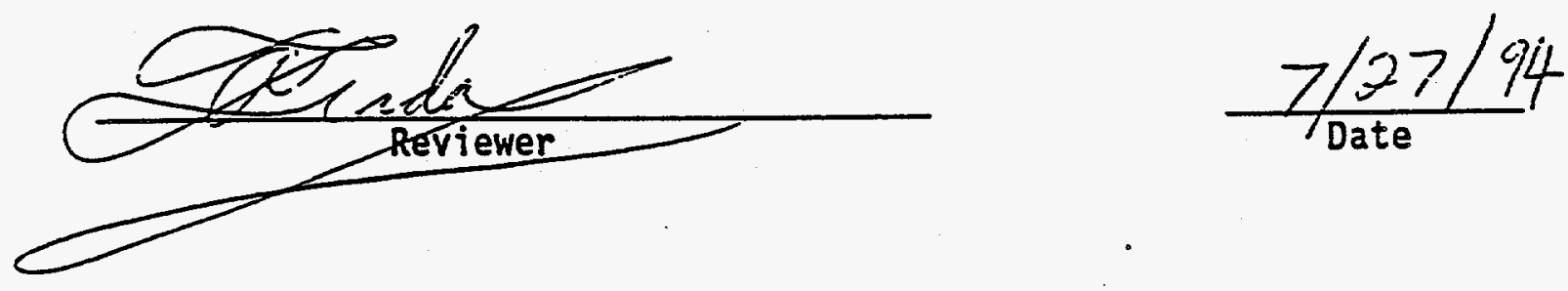
Document Reviewed Riser 3A Spray Wand Adapter Stress Analys is

Author D.A. Koehler

Document No.

Yes № N/A

[X] $\left[\begin{array}{lllll} & 1 & \text { P }\end{array}\right]$ Problem completely defined.

[X] [ ] [ ] Necessary assumptions explicitly stated and supported.

[ $1\left[\begin{array}{llll} & {[} & {[} & {[}\end{array}\right]$ Computer codes and data files documented.

[ $X_{Y}[$ [ [ ] Data used in calculations explicitly stated in document.

[X] [ ] [ ] Data checked for consistency with original source information as applicable.

[X] [ ] [ ] Mathematical derivations checked including dimensional consistency of results. [ ] [ ] [ $]$ Models appropriate and used within range of validity or

[X] [ ] [ ] Hand calculations checked for errors.

[ ] [ ] [ $X_{]}$Code run streams correct and consistent with analysis documentation. [ ] [ ] [ $\}_{]} \begin{aligned} & \text { Code output consistent with input and with results } \\ & \text { reported in analysis documentation. }\end{aligned}$

[X] [ ] [ ] Acceptability limits on analytical results applicable and supported. Limits checked against sources.

[X] [ ] [ ] Safety margins consistent with good engineering practices.

[X] [ ] [ ] Conclusions consistent with analytical results and applicable limits.

[X] [ ] [ ] Results and conclusions address all points required in the problem statement.

MANDATORY

Software QA $\log$ Number N/A
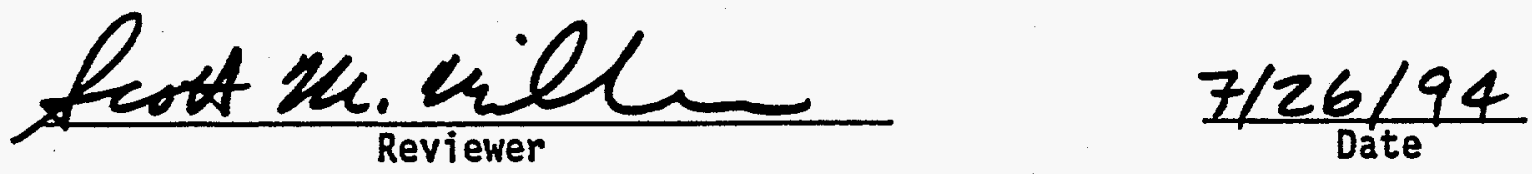


\section{DESIGN CALCULATION WHC-SD-WM-DA-169}

(1) Drawing $\mathrm{H}-2-82 / 382$

(2) Doc. No.

Page B-7

(4) Building $24 /-54-10 /$ (5) Rev.

(3) Page of 10

(7) Subject Riser $3 A$ Spray Hand Adapter Stress Anelusir

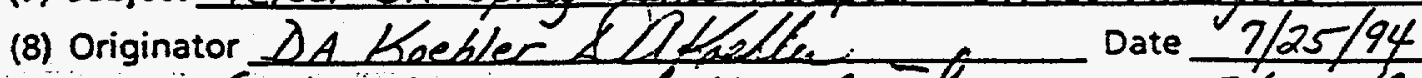

(9) Checker S.M.Micil A. H Re CDate 7/26/94

\section{Weight of Spray wand Adapter (Piser Adapter)}

The following calculations conservatively ertimate the weigit of the spray wand adapter. Each component of the spray wand adapter is calculated separately, jointly producing an upper bound to the totel weight.

Density of steel, $\rho_{s}=490 \mathrm{lbf} / \mathrm{ft}^{3}=0.2836 \mathrm{lbf/in}$ (Pytel 1987)

Cover PN44: Plate 55 Dia $\times 3$ the ASTM A36 CS

$$
\begin{aligned}
W_{1} & =p_{s}(3 \operatorname{in} .)\left[\frac{\pi}{4}\left(35^{2}-6.75^{2}-2(3)^{2}\right)\right] \\
& =776 \mathrm{l} 6 \mathrm{f} .
\end{aligned}
$$

Inner Pipe, PN 8: Pipe 6 Dia Schd 40 ASTM A53

$$
\begin{aligned}
W_{2} & =18.97 \mathrm{lbf} / \mathrm{ft}(1 \mathrm{ft} / 12 \mathrm{in.})(67.75 \mathrm{in.}) \\
& =107 \mathrm{lbf} .
\end{aligned}
$$

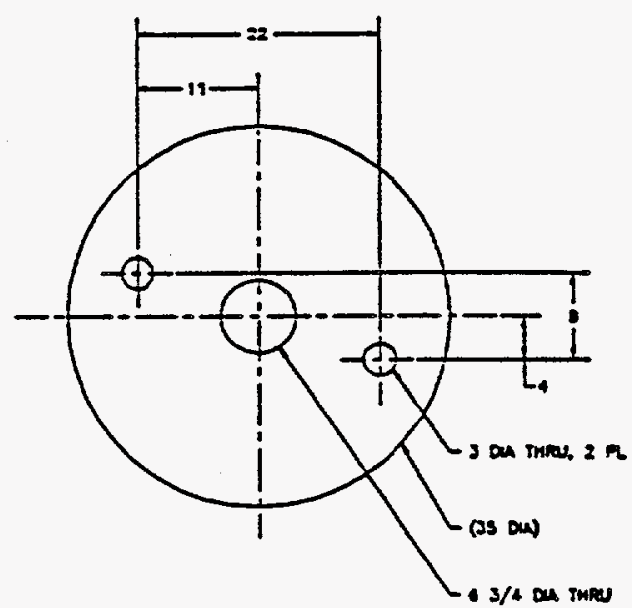

(4) COVER

outer Pipe PN 7 : Pije 14 Dia Schd to ASTM A53 The $12 \times 14$ Reducer will be irieluded in the weight of the outer pipe.

$$
\begin{aligned}
W_{3} & =63.44 \mathrm{lbf} / \mathrm{ft}(\mathrm{fft} / 12 \mathrm{in} .)(63.25 \mathrm{in.}) \\
& =334 \mathrm{lbf} .
\end{aligned}
$$


DESIGN CALCULATION

$$
\begin{aligned}
& \text { WHC-SD-WM-DA-169 } \\
& \text { REV } 0 \\
& \text { Page B-8 }
\end{aligned}
$$

(1) Drawing $H-2-82 / 38 z$

(2) Doc. No.

(6) Job No.

(4) Building $24 /-5 \%-10$,

(5) Rev. of 10

(7) Subject Riser $3 A$ Spray Hand Adopter Steers Analysis

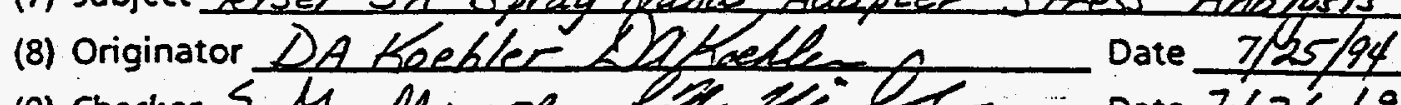

(9) Checker S.M.M icieR Date $7 / 26 / 94$

(10)

Steel Shot, sN 9: \#8 Shot

To be conservative, the cavity formed by the inner and outer pipe will be assumed solid.

$$
\begin{aligned}
W_{4} & =\rho_{s}\left(63.25 i_{.}\right)\left[\frac{\pi}{4}\left(13.124^{2}-6.625^{2}\right)\right] \mathrm{in}^{2} \\
& =1,808 \mathrm{l} \mathrm{ff} .
\end{aligned}
$$

Flange, PNG: 12 bia Blind 150 Class

$$
\begin{aligned}
W_{s} & =\rho_{s}(1.5 \mathrm{in})\left[\frac{\pi}{4}\left(19^{2}-6.75^{2}\right)\right] i_{\mathrm{n}^{2}} \\
& =105 \mathrm{lbf} .
\end{aligned}
$$

Lifting Lugs, PN5: Plate $1 / 2$ the ASTI ABE CS

Approximate weight by assuming a rectangle.

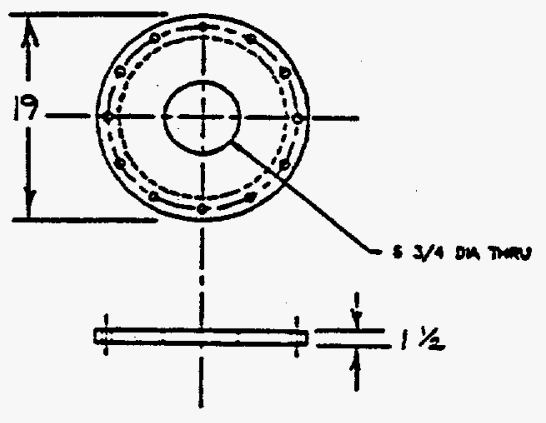

$$
\begin{aligned}
W_{6} & =p_{s}(0.5 \mathrm{in})(6 \mathrm{in} . \times 4 \mathrm{in})(2) \\
& =7 \mathrm{l} / 6 \mathrm{f} .
\end{aligned}
$$

(6) FLANGE, MODIFIED

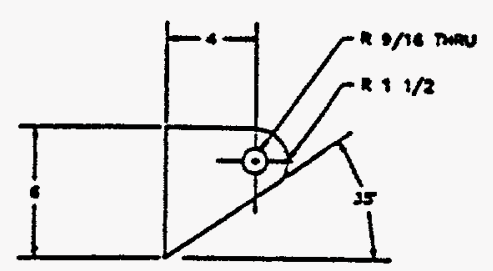

(5) LIT T LUG

$80.6400 .060 .1(12.87)$ 
DESIGN CALCULATION

(1) Drawing $H-2-82 / 382$

(2) Doc. No.

WHC-SD-WM-DA-169

REV 0

Page B-9

(4) Building $24 /-5 \psi-10 /$

(5) Rev.

(6) Job No.

(7) Subject Riser 3A Spray wand Adopter Stress Agalusi's

(8) Originator $D A$ heeler. Ll/ treble. Date $7 / 25 / 94$

(9) checker S.M.Micceil L.H Mil L Date 7126194

(10)

Shield Cap, RN: Plate $\phi 19 \times 3$ the ASTM A36 CS w/ Bail, plate I the ASTM A36 CS

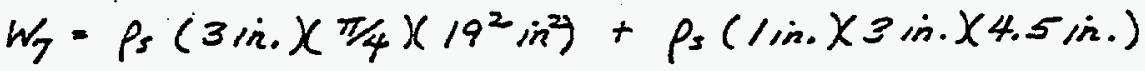

$$
\begin{aligned}
& =241+4 \\
& =245 \mathrm{lbf} \text {. }
\end{aligned}
$$

Total weight of spray wand adapter assembly, $w_{T}=\sum_{i=1}^{T} w_{i}$

$$
w_{T}=3,38216 f
$$

BD .6400.060 $:(12.87)$ 


\section{DESIGN CALCULATION WHC-SD-WM-DA-169}

REV 0

(1) Drawing $H-2-82 / 382$

(2) Doc. No.

Page B-10 10

(4) Building $24 \mid-5 Y-101$

(5) Rev.

(6) Job No.

(7) Subject Pisec $3 A$ Spony fand Adgoter Stress Anolysis

(8) Originator $\partial A$ Kaebler LDKagalle Date 7/25/94

(9) Checker S.M.M. CER L.E Kel Eate $7 / 26 / 94$

Lifting Analusis

The spray wand adapter will be iristalled using a spreader bar (H-2-821383) and the two lugs on the adapter.

The estiriated weight of the adapter is upproximately $3,382 \mathrm{lbf}$. For design purposes, the total weight of the adopter will be arsumed to be 3,500 lbf.

Assume a dynamic load facter (DLF) of 2.0 on all lifter.

Allowable Stress

Allowable tensile stress, $F_{t}=1 / 3 \sigma_{y}$ (DOE-RL $92-36$ 1993)

Allowable shear stress, $F_{s}=1 / 3 \tau_{y}$

For ASTM A36 CS,

$$
\begin{aligned}
& F_{t}=1 / 3(36,000)=12,00016 \mathrm{f} / \mathrm{in}^{2} \\
& F_{s}=1 / 3(18,000)=6,000 \mathrm{l} / \mathrm{f} / \mathrm{in}^{2} .
\end{aligned}
$$


DESIGN CALCULATION $\quad$ WHC-SD-WM-DA-169

REV 0

(1) Drawing $4-2-82 / 382$

(2) Doc. No.

Page B-11

(4) Building $24 \mid-54-10 /$

(5) Rev.

(6) Job No.

(7) Subject Riser ?A Spray upland Adapter Stress Analysis

(8) Originator $D A$ boehler Labeller Date $7 / 25$ fy

(9) Checker S, M. Nicer \&. M. Mil l Date $\$ 126194$

(10)

Lifting lugs, PN5: plate $1 / 2$ the

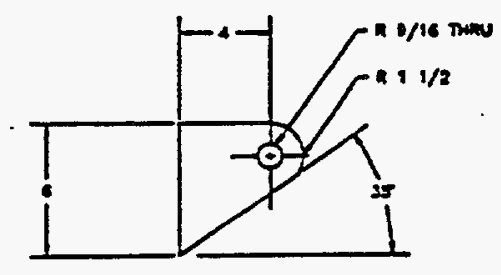

$$
\angle=3,50016 f
$$

(5) UFT LUG

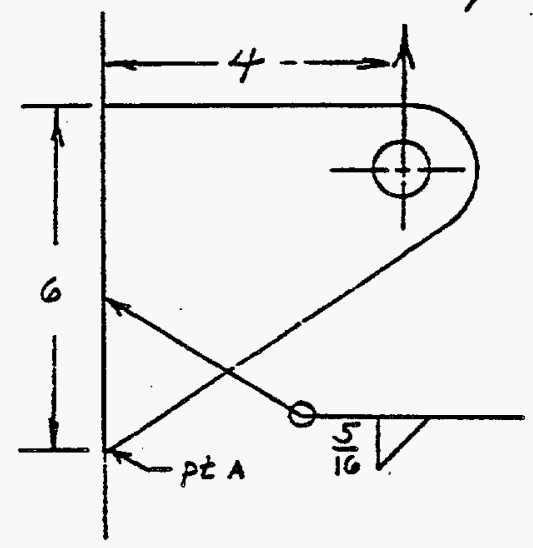

Moment at pt $A$,

$$
\begin{aligned}
M_{A} & =(3,500 \mathrm{lbf} \times(4 \mathrm{in}) \\
& =14,000 \mathrm{lbf}-i_{\mathrm{n}} .
\end{aligned}
$$

Moment of inertia at $p t$. A,

$$
\begin{aligned}
I_{A} & =\frac{1}{12}(1 / 2 \text { in. } \times 6 \text { in. })^{3} \\
& =9.0 \mathrm{in} 4
\end{aligned}
$$

Bending stress at pt. $A$,

$$
\begin{gathered}
f_{b_{A}}=\frac{M_{A} C}{I_{A}}=\frac{(14,00016 f-\dot{m} \cdot \times 3 \mathrm{in})}{9.0 \cdot \dot{n}^{4}}=4,667 \mathrm{lbf} / \mathrm{in}^{2} \\
f_{b_{A}}<f_{t} \rightarrow \text { OK }
\end{gathered}
$$

Weld fixing lug to $14-1$ in: pipe. Assume weld made with E60xx electrode. Ultimate strength of weldment is $60,000 \mathrm{lbf} / \mathrm{in}^{2}$, slightly higher than A5TM A36 CS. USe same allowable stresses as 136 .

Minimum failure area of weld,

$$
A_{w}=2(6 \text { in. })(5 / 16 \text { in. } X 1 / \sqrt{2})=2.65 i^{2}
$$

Moment of inertia of weld,

$$
I_{w}=\frac{1}{12}(2 \times 5 / 16 \text { in. } Y 1 / 12)(6 \mathrm{in})^{3}=8.0 \mathrm{in}^{4}
$$

$90.6400 .060 .1(12 / 87)$ 
DESIGN CALCULATION WHC-SD-WM-DA-169

REV 0

(1) Drawing $f-4 f-82 / 382$

(2) Doc. No.

Page B-12

(4) Building $24 /-54-10 /$

(5) Rev.

(6) Job No.

(7) Subject Riser 3A Spray wand Adapter Stress Analysis

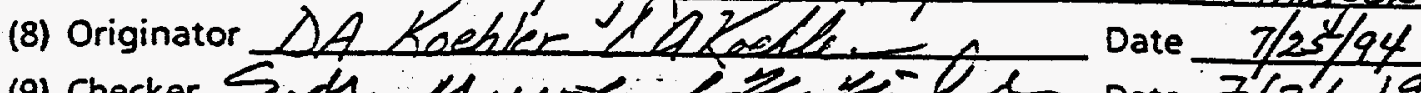

(9) Checker SiM. M,cesk $7 / 26194$

(10)

Bending stress at weld,

$$
\begin{gathered}
f_{b_{w}}=\frac{(14,000 \mathrm{lbf}-\operatorname{in})\left(3 \mathrm{in}_{0}\right)}{8.0 \mathrm{in}^{4}}=5,250 \mathrm{kbf/ \textrm {in } ^ { 2 }} \\
f_{b_{w}}<f_{t} \rightarrow 0 K
\end{gathered}
$$

Shear failure at hole.

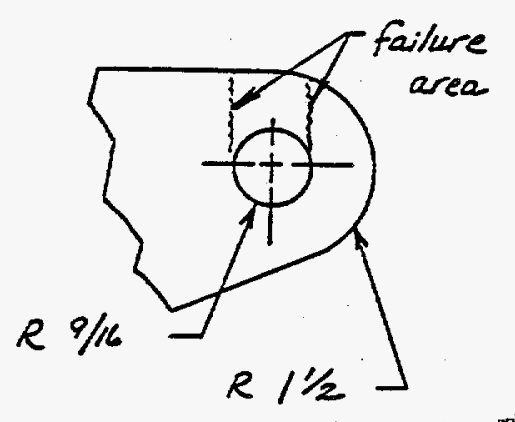

Shear area (Conservative),

$$
\begin{aligned}
A_{j} & =2(1.5-0.563 \times 0.5) \mathrm{in}^{2} \\
& =0.937 \mathrm{in}^{2} .
\end{aligned}
$$

Shear stress,

$$
f_{s}=\frac{3,500 \mathrm{lbf}}{0.937 \mathrm{in}^{2}}=3,735 \mathrm{lbf} / \mathrm{in}^{2}<F_{s} \rightarrow O K
$$

$8 D-6400-060.1(12 / 87)$ 
(1) Drawing $H-2-82 / 382$

(2) Doc. No.

Page B-13

7 of 10

(4) Building $241-54-101$

(5) Rev.

(6) Job No.

(7) Subject Riser 3 A Spray Hand Adnpter Stress Analusis

(8) Originator DA Koebler D27kelle Date 725194

(9) Checker S.M.M1ese-R

L

Date $7 / 26 / 94$

Assembly weldments

weld between outer pipe and cover.

- Minimum failure area ( $1 / 4-i n$. fillet),

$$
\begin{aligned}
A_{w} & =\pi(14 \text { in. })(1 / 4 \text { in } x / / \sqrt{2}) \\
& =7.8 i^{2} .
\end{aligned}
$$

Tensile stress at weld,

$$
\begin{gathered}
f_{t_{w}}=(7,000 \mathrm{kf}) / 7.8 \mathrm{in}^{2}=897 \mathrm{kf} / \mathrm{in}^{2} \\
f_{t w}<F_{t} \rightarrow \text { ok }
\end{gathered}
$$

All other weldments in the

adapter all not critical and are sized according to good

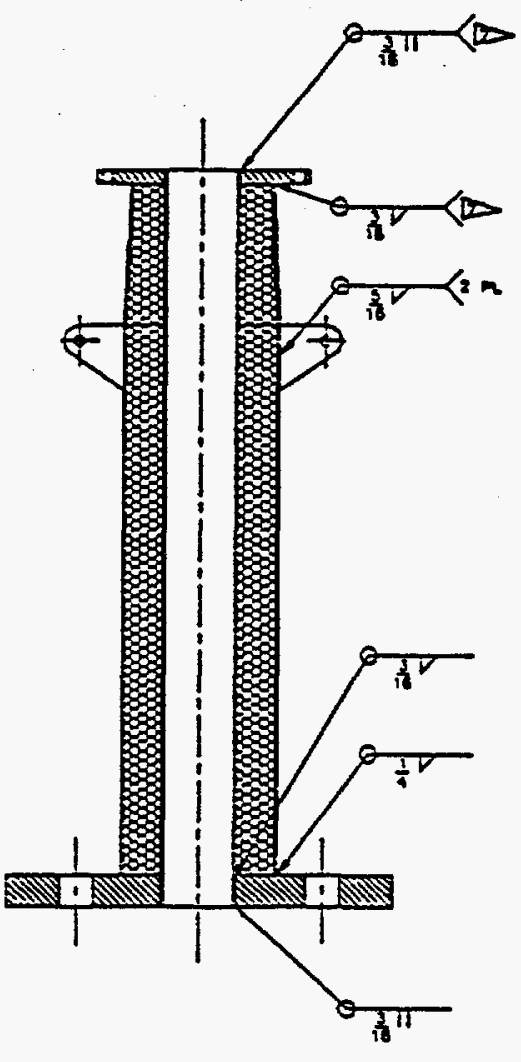
welding sractice. 
(1) Drawing $H-2-82 / 383$ (2) Doc. No. REV 0

(4) Building $24 /-54-10 /$ (5) Rev.

Page B-14 8 of 10

(7) Subject Piser $3 A$

(8) Originator $\triangle A$ koebler

(9) Checker $\sum, \mu_{1} M_{1}<$ etR (6) Job No.

(10) Spreader Bar (litting yoke)

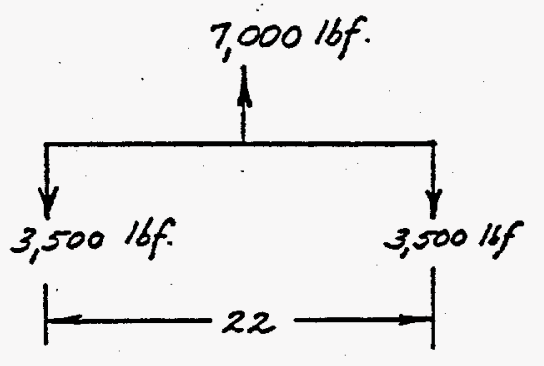

Maximum bending moment,

$$
M=(3,500 / 6 f \times / / \text { in. })
$$

$=38,500$ lbf-in.

Section modulur of $55 \times 14.75$ (AISC 1989),

$$
s=6.09 \text { in }^{3} \text {. }
$$

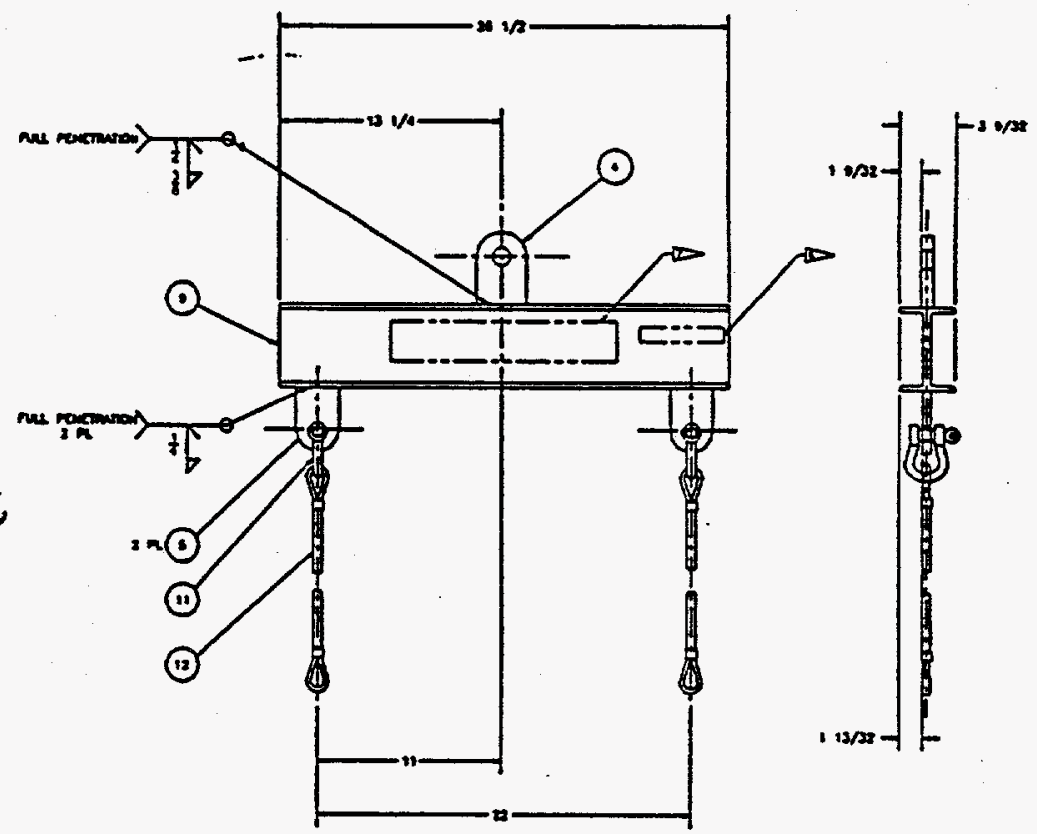

(1) RISER AOAPTER UTTING YOKE

Bending Stress in beam (ASTM A36 CS),

$$
f_{b}=\frac{M}{s}=\frac{38,500 \mathrm{lbf}-\dot{m}_{1}}{6.09 \mathrm{in}^{3}}=6,322 \mathrm{lbf} / \mathrm{in}^{2}<F_{t} \rightarrow \text { ok }
$$

Top Lug, PN 4 : Plate $3 / 4$ thk
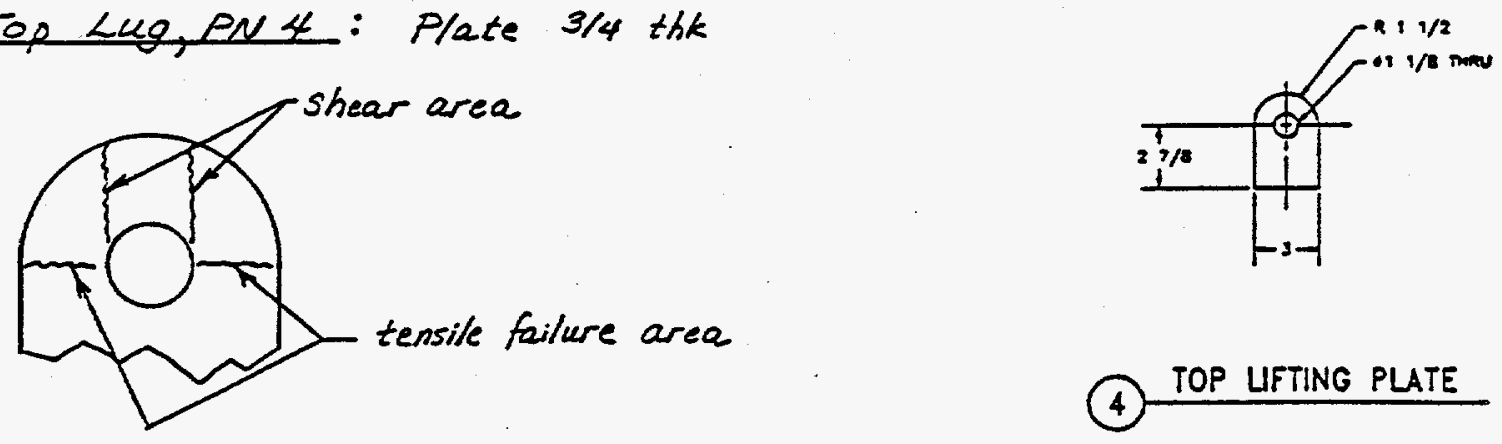

(4) TOP LIFTING PLATE 
DESIGN CALCULAT WHC-SD-WM-DA-169

REV 0

(1) Drawing $H-2-82 / 383$

(2) Doc. No.

Page B-15

(4) Building $24 /-5 y-10 /$

(5) Rev.

(6) Job No.

(7) Subject Riser $3 A$ Spray Wand Adapter Stress Analysis

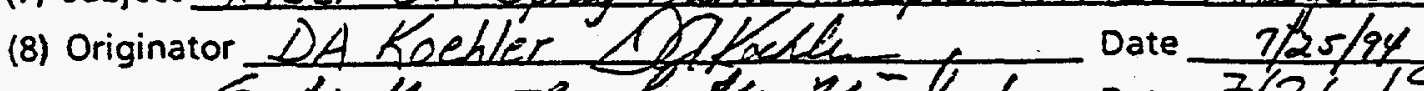

(9) Checker S. A.M.LLER Date $7 / 26 / 94$

(10)

Shear failure area (conservative estimate),

$$
A_{S}=0.75 \text { in. }(2)\left[1.5-\frac{1}{2}\left(1 \frac{1}{3}\right)\right] \text { in. }=1.407 \mathrm{in}^{2}
$$

shear stress,

$$
f_{s}=\frac{7,000 \mathrm{lbf}}{1.407 \mathrm{in}^{2}}=4,975 \mathrm{lbf} / \mathrm{in}^{2}<F_{s} \rightarrow \Delta K
$$

Tensile failure area,

$$
A_{t} \simeq A_{s}=1.407 \mathrm{in}^{2}
$$

Tensile stress,

$$
f_{t}=\frac{7,000 \mathrm{lbf}}{1.407 \mathrm{in}^{2}}=4,975 \mathrm{lbf} / \mathrm{in}^{2}<F_{t} \rightarrow 0 k
$$

weld fastening top lug to spreader bar. Assumed constructed using $E 60 x x$ electrode, $\sigma_{\text {ut }}=60,000 \mathrm{lsf} / \mathrm{in}^{2}$ weld is full penetration with a generous fillet. producing a greater cross section than the base metal of the lug. Therefore, no weld analysis is required.

Better Lugs, PN5: Plate $1 / 2$ the

Shear failure area

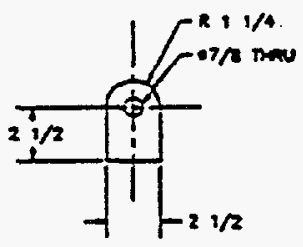

(5) BOTTOM UTT PLATE

$903300001 \div 297$ 
DESIGN CALCULA WHC-SD-WM-DA-169

Page B-16

(1) Drawing $y-2-82 / 383$

(2) Doc. No.

(2) $x_{2}$ e 10 of 10

(4) Building $24 /-5 y-10 /$

(5) Rev.

(6) Job No.

(7) Subject Riser $3 A$ Spray Wand Adapter Stress Analysis

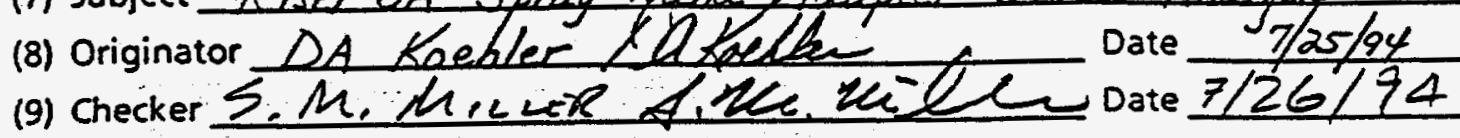

(10)

Shear failure area (conservative estimate),

$$
A_{s}=0.5 \mathrm{in.}_{.}(2)\left[1 \frac{1}{4}-\frac{1}{2}\left(\frac{7}{8}\right)\right] \mathrm{in.}_{0}=0.813 \mathrm{in}^{2}
$$

Shear stress,

$$
f_{s}=\frac{3,500 \mathrm{lbf}}{0.813 \mathrm{in}^{2}}=4,308 \mathrm{lbf} / \mathrm{in}^{2}<F_{s} \rightarrow 0 K
$$

Tensile failure area,

$$
A_{t}=A_{s}=0.213 \mathrm{in}^{2}
$$

Tensile stress,

$$
f_{t}=\frac{3,500 \mathrm{lbf}}{0.813 \mathrm{in}^{2}}=4,308 \mathrm{lbf} / \mathrm{in}^{2}<f_{t} \rightarrow \text { ot }
$$

Weld fastening bottom lug to spreader bar. Assumed constructed using E60xx electrode. Weld is full penetration with a generous fillet producing a greater cross section thin the base metal of the lug. Therefore, no weld analysis is required.

$30.6400 \cdot 060.1\{12.37\}$ 


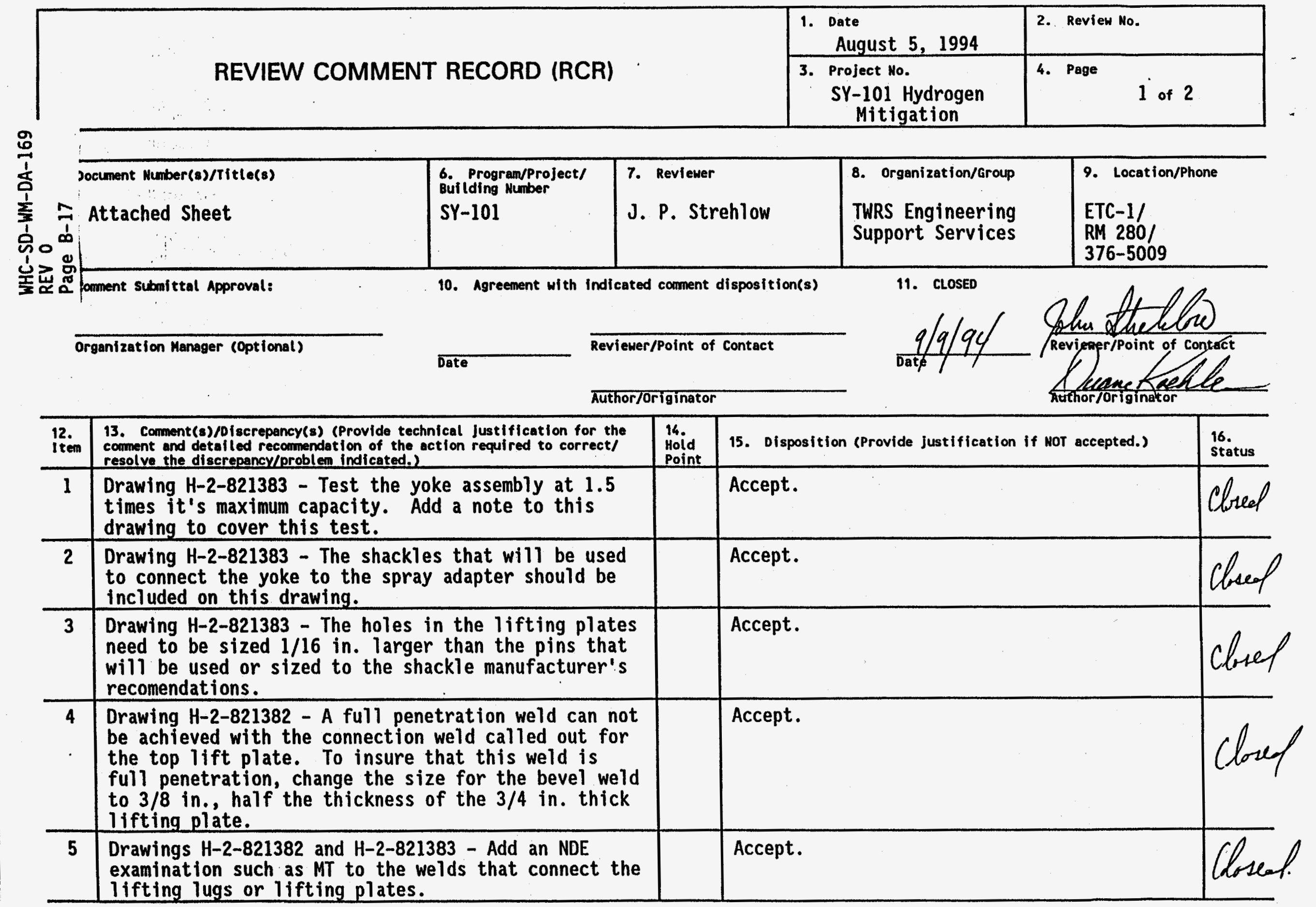

A-6400-090.1 (03/92) WEF011 
From: Mechanical Engineering

Phone: $\quad 376-3244$ H5-70

Date: August 17, 1994

Subject: STRUCTURAL ANALYSIS OF RISER 3A SPRAY WAND ADAPTER (Comments Incorporated)

To:

S. W. Shaw
CC: R. E. Russell
J. P. Strehlow DAK-FiTe/LB

References: AISC, 1989, Allowable Stress Design, American Institute of Steel Construction, Chicago, Illinois.

DOE-RL, 1993, Hanford Site Hoisting and Rigging Manual, DOE-RL $92-36$, U.S. Department of Energy, Richi and Operations Office, Richland, Washington.

Pytel, A., and F. L. Singer, 1987, Strength of Materials, Fourth Edition, Harper and Row, Publishers, New York, New York.

WHC, 1994a, Riser $3 A$ Spray Wand Adapter, drawing H-2-821382, Westinghouse Hanford Company, Richland, Washington.

WHC, 1994b, Riser Adapter Lifting Yoke, drawing H-2-821383, Westinghouse Hanford Company, Richland, Washington.

Review comments from J. P. Strehlow were incorporated in the structural analysis of the riser $3 A$ spray wand adapter. The attached structural analysis represents the revised version.

The riser $3 \mathrm{~A}$ spray wand adapter (drawing $\mathrm{H}-2-821382$ ) and 1 ifting yoke (drawing H-2-821383) were structurally analyzed for lifting and found acceptable per criteria given in the Hanford Site Hoisting and Rigging Manual. The rigging manual states that maximum stress shall not exceed one-third of the minimum yield strength of the material.

The weight of the spray wand adapter is estimated at 3,385 lbf including the shield cap. This weight is an upper bound to the actual weight, which will be significantly less. The shield cap weighs considerably more than the drill rod washer, so it was included in the weight estimate instead of the washer. The steel shot cavity was assumed solid, conservatively increasing the estimated weight of the adapter. 
S. W. Shaw

Page 2

August 17, 1994

WHC-SD-WM-DA-169

REV 0

Page B-20

For design purposes, the weight of the adapter was assumed to be 3,500 lbf. A dynamic load factor (DLF) of 2.0 was assumed for conservatism. The structural analysis focused principally on the lifting lugs of the adapter and spreader bar (lifting yoke). The lugs were analyzed for tensile and bending failure, shear tear out, and adequacy of connecting welds. The critical welds of the adapter assembly also were evaluated and found acceptable.

All questions regarding the attached analysis should be directed to D. A. Koehler at $376-3244$.

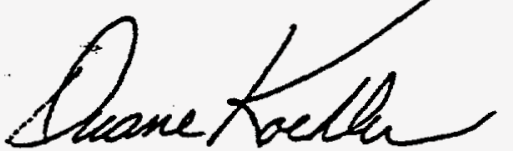

D. A. Koehler, Engineer Mechanical Engineering

$1 \mathrm{kph}$

Attachment 
WHC-SD-WM-DA-169
REV 0

Page B-21

INDEPENDENT REVIEW

Document Reviewed Riser 3A Spray Wand Adapter Stress Analysis

Author D.A. Koehler Document No. EDT No.

The subject document has been reviewed by the undersigned. The reviewer reviewed and verified the following items as applicable [EP.4.1, Rev. 3].

- Engineering Specification

- Design Input

- Basic Assumption

- Approach/Design Methodology

- Related Information

- Conclusion/Result Interpretation
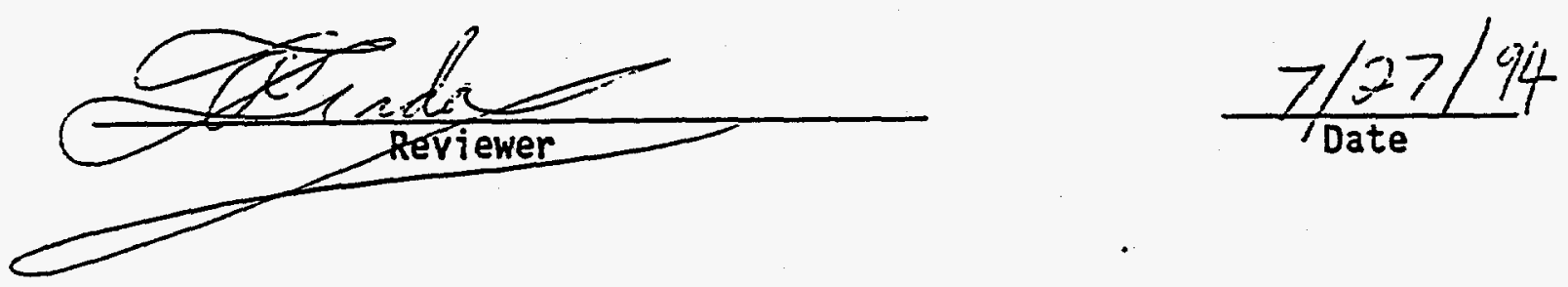
Document Reviewed Riser 3A Spray Wand Adapter Stress Analysis

Author D.A. Koehler

Document No.

Yes № N/A

[X] [ ] [ ] Problem completely defined.

[X] [ ] [ ] Necessary assumptions explicitiy stated and supported.

[ ] [ ] [ $[$ ] Computer codes and data files documented.

$\left[X_{[}[][]\right.$Data used in calculations explicitly stated in document.

[X] [ ] [ ] Data checked for consistency with original source information as applicable.

[ $[$ [ ] [ ] Mathematical derivations checked including dimensional consistency of results. [ ] [ ] [ $]$ Models appropriate and used within range of validity or

[X] [ ] [ ] Hand calculations checked for errors.

[ ] [ ] [ $]$ ] code run streams correct and consistent with analysis documentation.

[ ] [ ] [Y] code output consistent with input and with results reported in analysis documentation.

$[X][][]$ Acceptability limits on analytical results applicable and supported. Limits checked against sources.

[X] [ ] [ ] Safety margins consistent with good engineering practices. [X] [ ] [ ] Conclusions consistent with analytical results and $[X]\left[1[1] \begin{array}{l}\text { Results and conclusions address all points required in the } \\ \text { problem statement. }\end{array}\right.$

MANDATORY SOftware QA Log Number

N/A
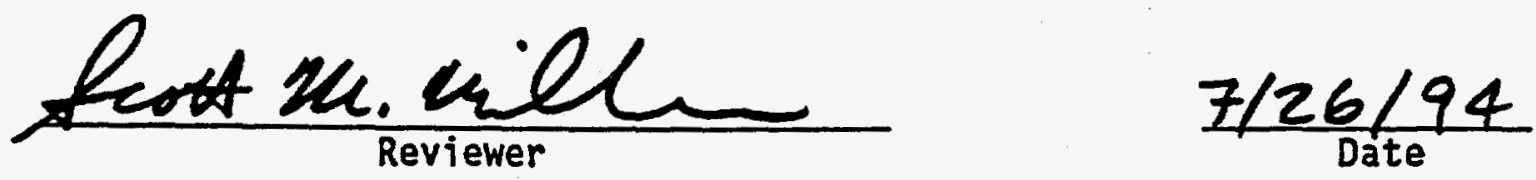
$\because$

DESIGN CALCULAT WHC-SO-WM-DA-169

(1) Drawing $H-2-82 / 382$

(2) Doc. No.

Page B-23

(4) Building $241-5 x-10 /$

(5) Rev.

(6) Job No.

(7) Subject Riser $3 A$ Spray hand Adapter Stress Analysis

(8) Originator $D A$ feebler A Cholla Date $\frac{7 / 25 / 94}{7 / 26 / 94}$

(9) checker S.M. Mu, IR $^{2}$ Date $7 / 26 / 94$

(10)

Weight of Spray wand Adopter (Riser Adapter)

The following calculations conservatively estimate the weight of the sprag wand adapter. Each component of the spray wand adapter is calculated separately, jointly producing an upper bound to the total weight.

Density of steel, $\rho_{s}=490 \mathrm{lbf} / \mathrm{ft}^{3}=0.2836 \mathrm{lbf} / \mathrm{in}^{3}$ (Pytel 1987)

Cover, PN4 : Plate 35 Dian $\times 3$ the ASTM A36 CS

$$
\begin{aligned}
W_{1} & =\rho_{s}(\sin )\left[\frac{\pi}{4}\left(35^{2}-6.75^{2}-2(3)^{2}\right)\right] \\
& =776 \mathrm{lbf} .
\end{aligned}
$$

Inner Pipe, PN 8: Pipe 6 Did Sch 40 ASTI AS

$$
\begin{aligned}
W_{2} & =18.97 \mathrm{lbf} / \mathrm{ft}(1 \mathrm{ft} / 12 \mathrm{in})(67.75 \mathrm{in}) \\
& =107 \mathrm{lbf} .
\end{aligned}
$$

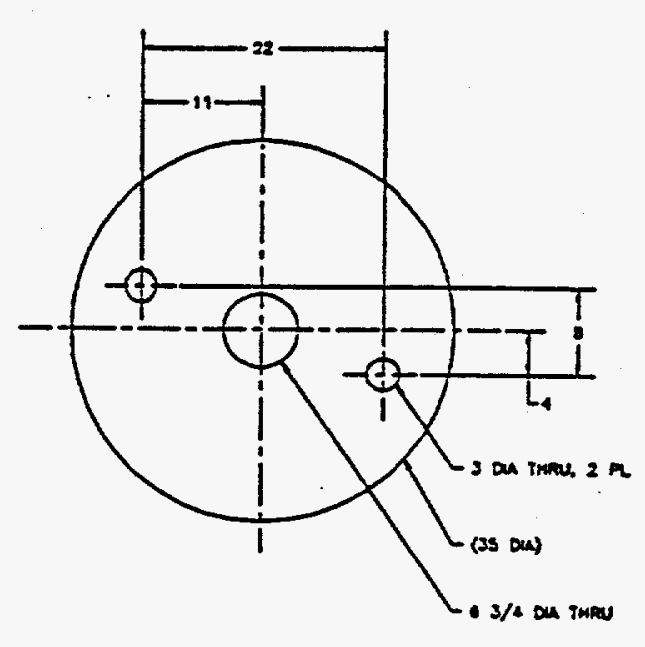

(4) COVER

Outer Pipe, PNI: Pipe 14 Die Sch 70 ATM AS The $12 \times 14$ Reducer will be included in the weight of the. outer pipe.

$$
\begin{aligned}
W_{3} & =63.44 \mathrm{lbf} / \mathrm{ft}(\mathrm{ft} / \mathrm{/2} \mathrm{in} .)(63.25 \mathrm{in}) \\
& =334 \mathrm{lof} .
\end{aligned}
$$

$B D-6400.060 .1(12 ; 87)$ 
(1) Drawing $4-2-82 / 382$ (2) Doc. No.

Page B-24 ige 2 of 10

(4) Building $24 /-5 y-10 /$ (5) Rev. (6) Job No.

(7) Subject Piser $3 A$ Spray Hand Adapter Sters Anafusis

(8) Originator $D A$ beebler LU batle Date 7/25/94

(9) Checker S.M.Miciel H Date $7 / 26 / 94$

Steel shot, pN 9: \#8 Shot

To be conservative, the cavity formed by the ininer and outer pipe will be assumed solid.

$$
\begin{aligned}
W_{4} & =\rho_{s}(63.25 \mathrm{in.})\left[\frac{\pi}{4}\left(13.124^{2}-6.625^{2}\right)\right] \mathrm{in}^{2} \\
& =1,808 \mathrm{lbf} .
\end{aligned}
$$

Flange, PNG: 12 Dia Elind 150 Class

$$
W_{5}=\rho_{S}(1.5 \mathrm{in})\left[\frac{\mathrm{T}}{4}\left(19^{2}-6.75^{2}\right)\right] \dot{i n}^{2}
$$$$
=105 \mathrm{lbf} \text {. }
$$

\section{Lifting luas, PN5: Plate $3 / 4$ thk ASTM A36 CS}

Approximate weight by assuming a rectangle.

$$
\begin{aligned}
W_{6} & =p_{s}(0.75 \mathrm{in})(6 \mathrm{in.} x 4 \mathrm{in})(2) \\
& =10 \mathrm{lbf}
\end{aligned}
$$

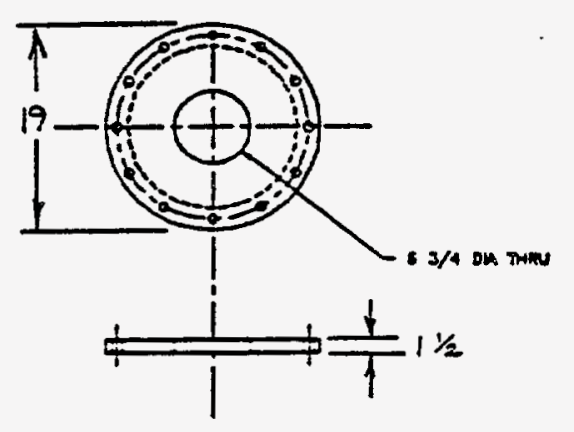

(6) FLANGE, MODIFIED

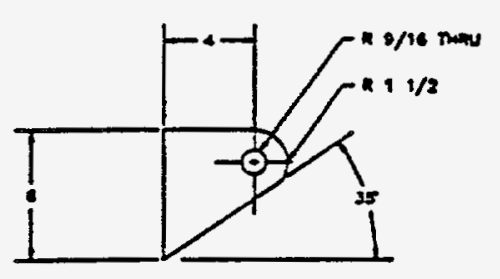

(5) LFT LUE 
DESIGN CALCULAT WHC-SD-WM-DA-169

REV 0

(1) Drawing $4-2-821382$

(2) Doc. No.

Page B-25

3 of 10

(4) Building $24 /-5 y-10 /$

(5) Rev.

(6) Job No.

(7) Subject Riser $3 A$ Sargy wand Adopter Stress Analusis

(8) Originator $D A$ Keebler LVy Date $7 / 25 / 94$

(9) Checker S.M.Miceri L H Mile Date F/26194

(10)

Whield Cap, PNZ: Plate $\phi 19 \times 3$ thk ASTM A36 CS

w/ Bail, plate, the ASTM $136 \mathrm{CS}$

$$
\begin{aligned}
W_{7} & =p_{s}(3 \mathrm{in} \cdot)(\pi / 4)\left(19^{2} \mathrm{in}^{2}\right)+p_{s}(1 \mathrm{in} \cdot x 3 \mathrm{in} \cdot \times 4.5 \mathrm{in} .) \\
& =241+4 \\
& =245 \mathrm{lbf} .
\end{aligned}
$$

Total weight of spray usand adzpter azsemcly, $w_{T}=\sum_{i=1}^{T} W_{i}$ $W_{T}=3,385 \quad 16 f$

$B 0.6200 .060:(12.87)$ 
DESIGN CALCULI WHC-SD-WM-DA-169

REV 0

(1) Drawing $H-2-82 / 382$

(2) Doc. No.

Page B-26

ge 4 of 10

(4) Building $24 /-5 Y-10 /$

(5) Rev.

(6) Job No.

(7) Subject Riser $3 A$ Some wind Adopter Stress Analysis

(8) Originator $\Delta A$ babbler 12 hague Date $\frac{7}{7 / 25 / 94}$

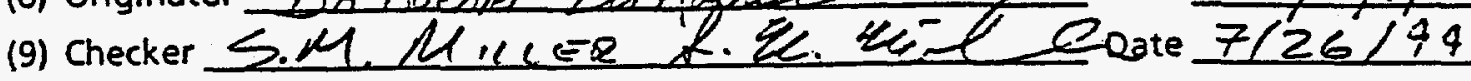

(10)

Lifting Analysis

The spray wand adapter will be installed using a spreader bar (H-2-82/383) and the two lugs on the adapter.

The estimated weight of the adapter is approximately $3,385 \mathrm{lbf}$. For design purposes, the total weight of the adapter will be armed to be $3,50016 f$.

Assume a dynamic load factor ( $2 L f F)$ of 2.0 on all lifts.

Allowable Stress

Allowable tensile stress, $F_{t}=1 / 3 \sigma_{y}$ (DOE-RL $92-36$ 1993) Allowable shear stress, $F_{s}=1 / 3 \tau_{y}$

For ASTM A36 CS,

$$
\begin{aligned}
& F_{t}=1 / 3(36,000)=12,000 \mathrm{l} / \mathrm{f} / \mathrm{in}^{2} \\
& F_{s}=1 / 3(18,000)=6,000 \mathrm{l} / \mathrm{f} / \mathrm{in}^{2}
\end{aligned}
$$

Allowable bending stress = Allowable tensile stress

$30.6400 .0601(12.87)$ 
(1) Drawing $\mathrm{H}-2-821382$

(2) Doc. No. _ Page B-27

Page 5 of 10

(4) Building $24 /-5 y-101$ (5) Rev.

(6) Job No.

(7) Subject Riser $3 A$ ifray Ward Adapter Stress Acalusis

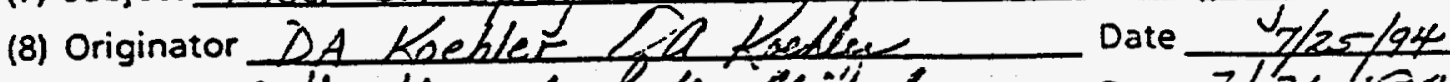

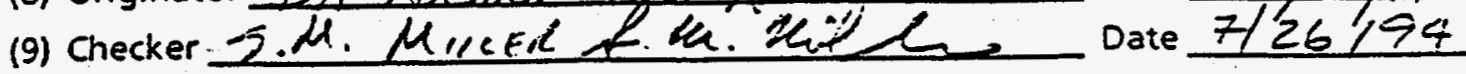

(10)

Lifting Lios, PNS: plate 3/4" the, ASTM A36
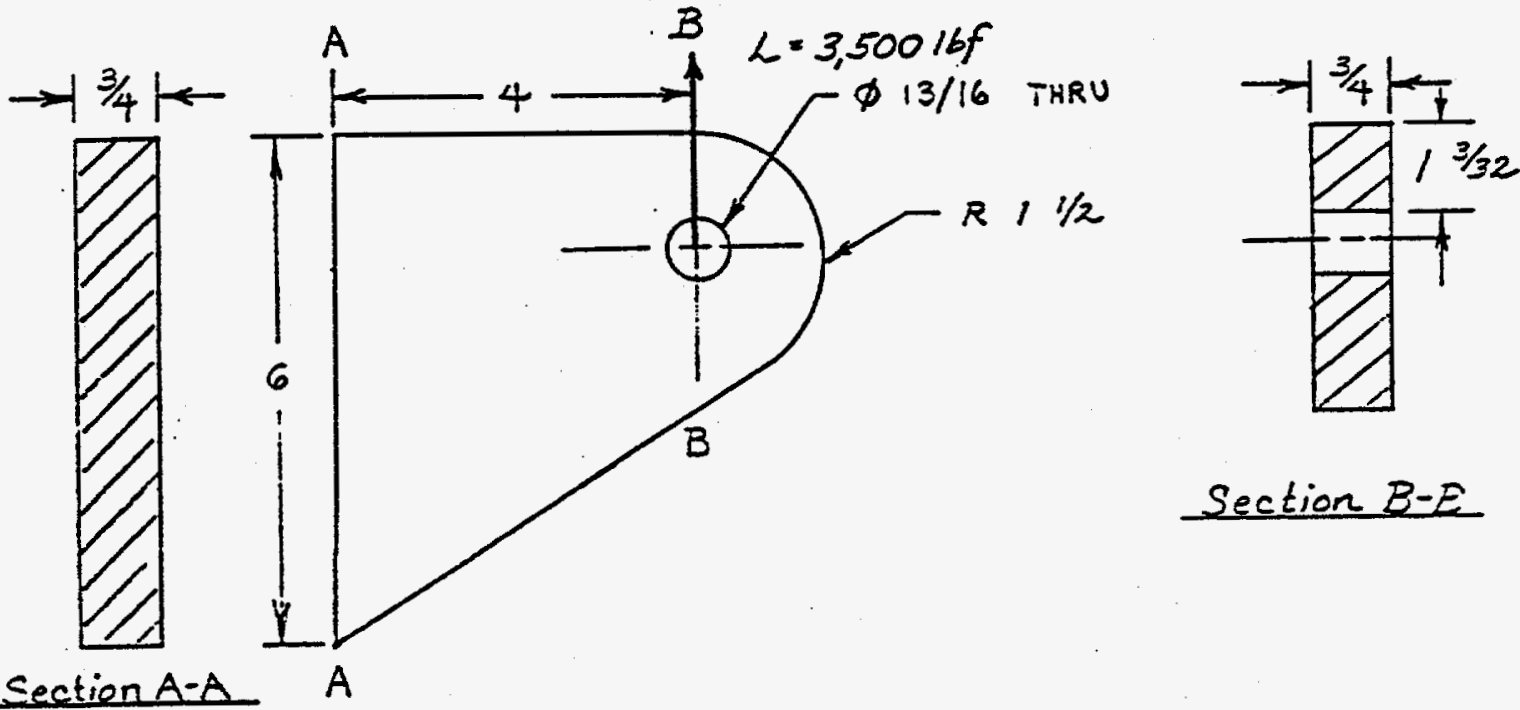

Section $B-E$

Moment at $A-A$,

$$
M_{A}=(3,500 \mathrm{lbf} \times 4 \mathrm{in} .)=14,000 \mathrm{lbf}-\mathrm{in} .
$$

Moment of Inertia at $A-A$,

$$
I_{1}=\frac{1}{12}\left(3 / 4 \mathrm{in} \cdot(6 \mathrm{in})^{3}=13.5 \mathrm{in}\right.
$$

Bending stress at $A \cdot A$,

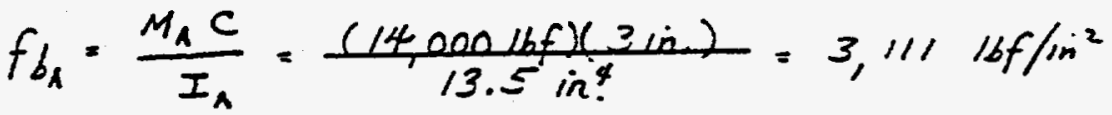

$$
\begin{aligned}
& f_{b_{A}}<F_{t} \rightarrow o k
\end{aligned}
$$

Shear stress at $B-B$,

$$
f_{s_{B}}=\frac{3,500 \mathrm{lbf}}{2(3 / 4 X / 3 / 32)}=2,13216 \mathrm{f} / \mathrm{in}^{2}<f_{S} \rightarrow O K
$$


REV 0

(1) Drawing $A-2-82 / 382$

(2) Doc. No.

Page B-28

ge 6 - of 10

(4) Building $24 /-5 K-10 /$

(5) Rev.

(6) Job No.

(7) Subject Diser $3 A$ Spray hland Adapter Steer Analusis

(8) Originator DA Koehler

(9) checker 3 . $\mu . \mu$ L LEP \&. th.

Date

Date $7 / 26 / 94$

(10)

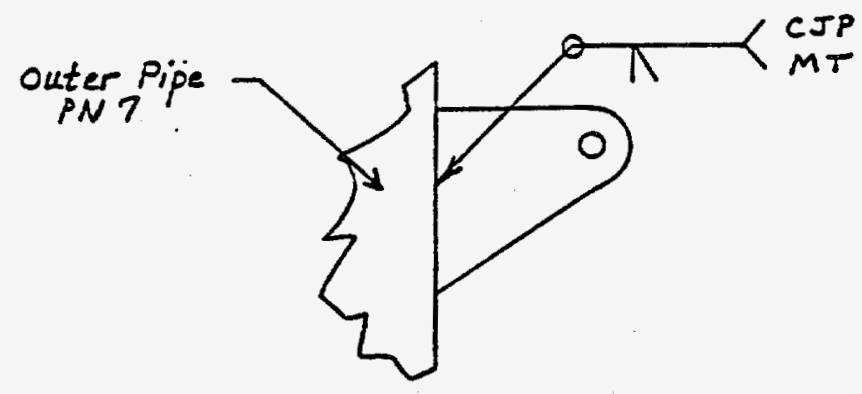

Weld fixing lug to 1 t-in. pipe. Assume weld made with Ecoxx electrode, $\sigma_{u}=60,000 \mathrm{lbf} / \mathrm{in}^{2}$. ultimate strengich of weld is sligntly higher than base metal, ASTM $136, \sigma_{u}=58,000 \mathrm{lbf} / \mathrm{in}^{2}$. since weld is full penetration and weld failure area is equivalent to the baie metal cross-section, no further weld analysis is necersary.

Shear failure at hole,

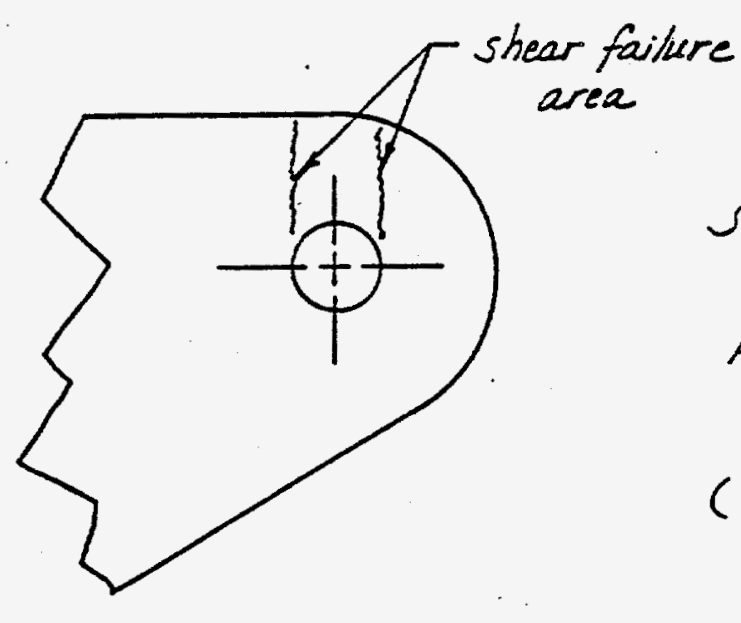

Shear failure area,

$$
\begin{aligned}
& A_{5}=2\left(1 / 2-\frac{1}{2}\left(\frac{13}{16}\right)\right)(3 / 4) \text { in }^{2} \\
& =1.64 / i^{2}
\end{aligned}
$$

Shear stress,

$$
f_{s}=\frac{3,500 / 6 f}{1.641 \mathrm{in}^{2}}=2,133 \mathrm{lbf} / \mathrm{in}^{2}<F_{s} \rightarrow \text { OK }
$$



(1) Drawing $4-2-82 / 382$
(2) Doc. No.
Page B-29
ie 7 of 10
(4) Building $24 /-5 y-10 /$
(5) Rev.
(6) Job No.
(7) Subject Riser 3A Spray wand Adapter Stress Analucis
(8) Originator $\lambda A$ Keebler All Woelles Date $7 / 25 / 94$
(9) Checker $\sum$ M.M.LER H. H. U.V Date $7126 / 94$

(10)

Assemb/4 Weldments

Critical weld: weld between outer pipe (PN7) and cover $($ PN 4$)$.

Minimum failure area of $1 / 4-i n$. fillet,

$$
\begin{aligned}
A_{w} & =\pi(14 \mathrm{in.} \times 1 / 4 \mathrm{in})(1 / \sqrt{2}) \\
& =7.8 \mathrm{in}^{2}
\end{aligned}
$$

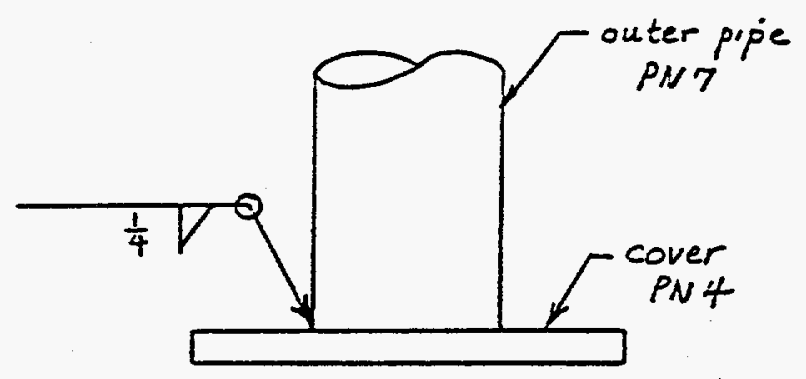

Assume fillet weld fails in shear.

Shear stress on weld,

$$
\begin{gathered}
f_{s_{w}}=\frac{7000 \mathrm{lbf} .}{7.8 \mathrm{in}^{2}}=897 \mathrm{lbf} / \mathrm{in}^{2} \\
f_{s_{w}}<f_{s} \rightarrow 0 \mathrm{~K}
\end{gathered}
$$

All other welds in the adapter (excluding the lifting lug welds) are not critical and are sized according to good welding practice. 
DESIGN CALCULI*

$$
\begin{aligned}
& \text { WHC-SD-WM-DA-169 } \\
& \text { REV } 0
\end{aligned}
$$

(1) Drawing $H-2-82 / 383$

(2) Doc. No.

Page B-30

e. 8 of 10

(4) Building $24 \mid-54-101$

(5) Rev.

(6) Job No.

(7) Subject Riser $3 A$ Spray Wand Adapter Stress Analysis

(8) Originator $\frac{\partial A \text { Koebler Lfeballe }}{S M}$ Date $\frac{7 / 25 / 94}{7 / 26 / 44}$

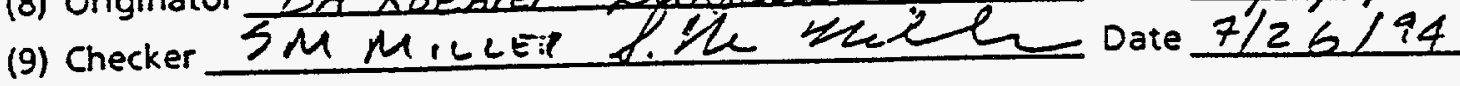

(10)

Riser Adapter Lifting Yoke (Spreader Bar)

Maximum Capacity 5,000 If.

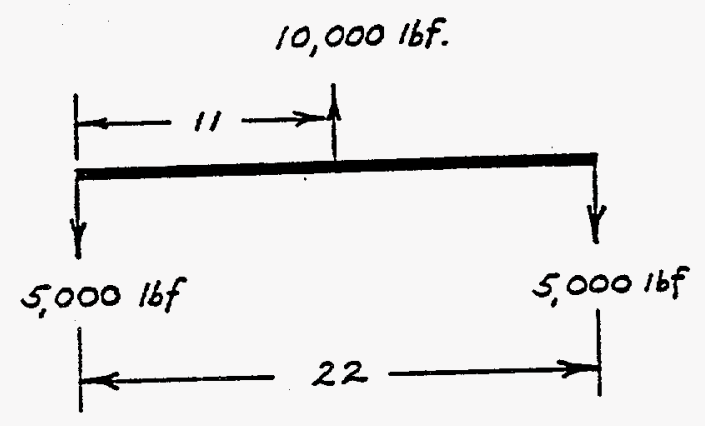

Maximum Bending Moment,

$$
M=5,00016 f(11 \text { in. })=55,000 \mathrm{in}-16 \hat{f}
$$

Section Modulus of $55 \times 14.75$,

$$
S=6.09 \text { in }^{3} \quad \text { (ANC 1989) }
$$

Bending Stress in Beam,

$$
f_{b}=\frac{M}{S}=\frac{55,000 \mathrm{in}-16 f}{6.09 \mathrm{in}^{3}}=9,03116 \mathrm{f} / \mathrm{in}^{2}<F_{t} \rightarrow 0 K
$$

Top Le, PN4: Plate 1 the

Shear failure area

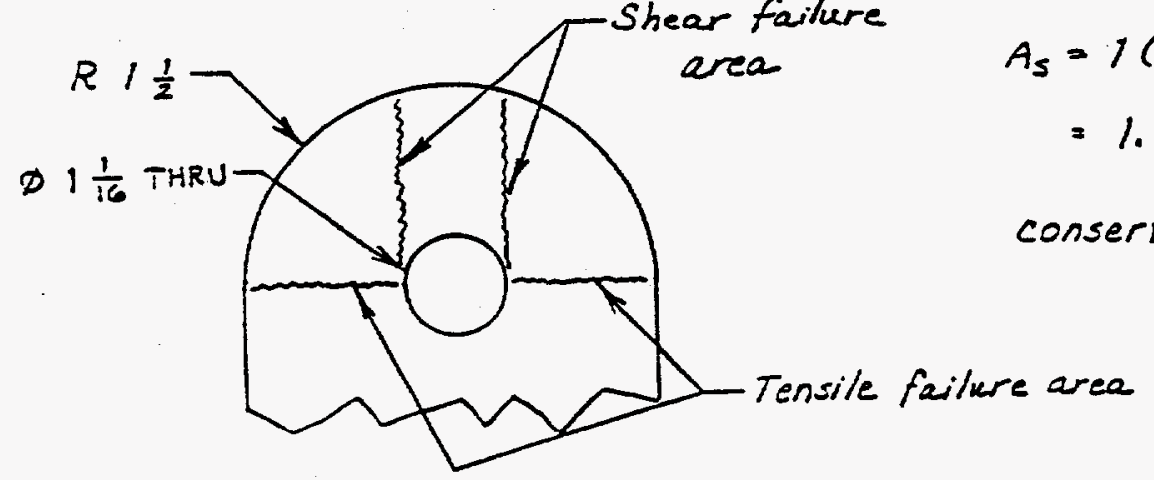

Shear failure area,

$$
\begin{aligned}
A_{s} & =7(2)\left[1 \frac{1}{2}-\frac{1}{2}\left(1 \frac{1}{16}\right)\right] \dot{i n}^{2} \\
& =1.938 \mathrm{in}^{2}
\end{aligned}
$$

conservative estimate

SD .6400.060 (1287) 
DESIGN CALK WHC-SD-WM-DA-169

REV 0

(1) Drawing $H-2-82 / 383$

(2) Doc. No. - Page B-31

3) Page $q$ of 10

(4) Building $24 /-5 \psi-10 /$

(5) Rev.

(6) Job No.

(7) Subject Riser 3A Spray Wand Adapter Stress Analysis

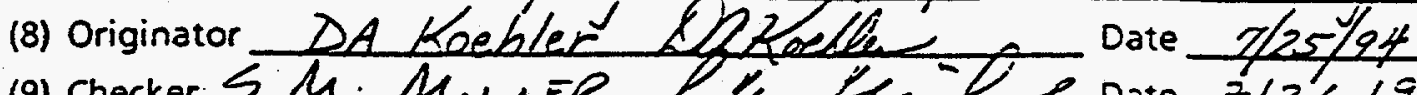

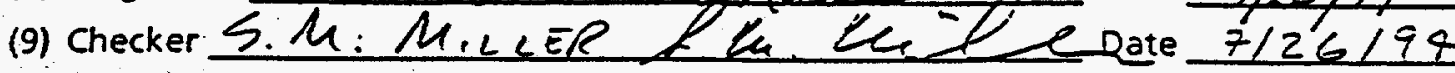

(10)

Shear stress,

$$
f_{s}=\frac{10,000 / 6 f}{1.938 \mathrm{in}^{2}}=5,161 / 6 \mathrm{f} / \mathrm{in}^{2}<F_{s} \rightarrow O K
$$

Tensile failure area,

$$
A_{t} \approx A_{s}=1.938 \mathrm{in}^{2}
$$

Tensile stress,

$$
f_{t}=\frac{10,000 \mathrm{lbf}}{1.938 \mathrm{in}^{2}}=5,16 / 16 \mathrm{f} / \mathrm{im}^{2}<f_{t} \rightarrow \Delta K
$$

Weld fixing top lug to spreader bar. Assume weld mate with $E 60 x x$ electrode, $\sigma_{u}=60,000 \mathrm{lbf} / \mathrm{in}^{2}$. Ultimate strength of weld is slightly higher than base metal, ASTM A36, $\sigma_{u}=58,000 \mathrm{lbF} / \mathrm{in}^{2}$. Since weld is full penetration and weld failure area is larger than the base metal cross-section, no further weld analysis is necessary.

Bottom Lugs, prS: Plate $2 / 4$ the

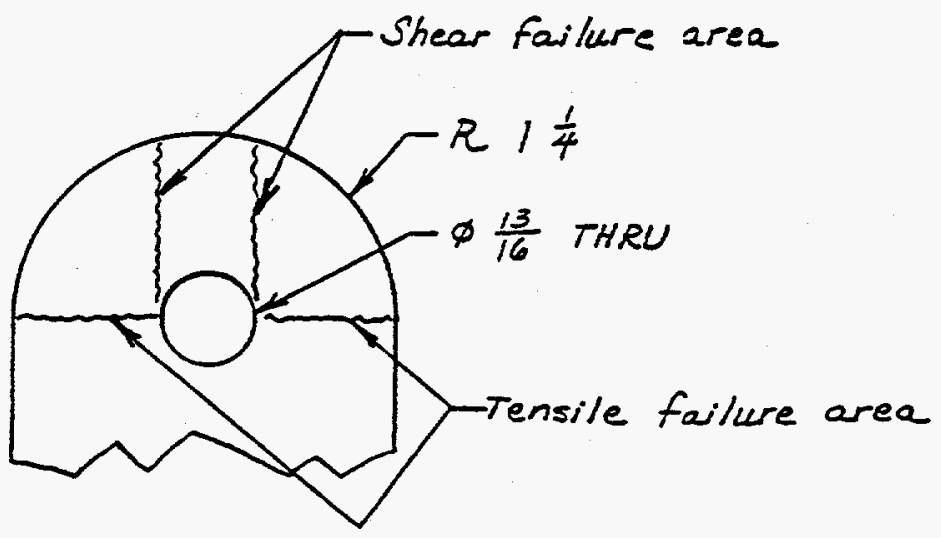

$90.6400 .060+(i 2.37)$ 
(1) Drawing $H-2-82 / 383$

(4) Building $24 /-5 Y-10 /$ (2) Doc. No.

Page B-32

je 10 of 10 (6) Job No.

(7) Subject Riser $3 A$ Serey yland Adapter Stress Analysis

(8) Originator $\triangle A$ Koebler

(9) Checker $5 \mu$ u. LCER d.U. Date $7 / 25 / 94$

Shear failure area,

$$
\begin{aligned}
& A_{5}=\frac{3}{4}(2)\left[1 \frac{1}{4}-\frac{1}{2}\left(\frac{13}{16}\right)\right] \text { in }^{2}=1.266 \mathrm{in}^{2} \\
& \text { conservative estimate }
\end{aligned}
$$

Shear stress,

$$
f_{s}=\frac{5,00016 f}{1.266 \mathrm{in}^{2}}=3,949 \mathrm{l} / \mathrm{f} / \mathrm{in}^{2}<F_{s} \rightarrow 0 k
$$

Tensile failure area,

$$
A_{t} \approx A_{s}=1.266 \mathrm{in}^{2}
$$

Tensile stress,

$$
f_{t}=\frac{5,000 \mathrm{lbf}}{1.266 \mathrm{in}^{2}}=3,949 \mathrm{lbf} / \mathrm{in}^{2}<F_{t} \rightarrow \text { ox }
$$

Weld fixing bottom lug to spreader bar. Assume weld made with $E 60 \times x$ electrode, $\sigma_{u}=60,000 \mathrm{lbf} / \mathrm{in}^{2}$. U/timate strength of weld is slightly higher than base metal, ASTM A36, $\sigma_{u}=58,000 \mathrm{iff} / \mathrm{in}^{2}$. Since weld is fall penetration and we/d failure area is larger than the base metal cross-section, no further weld analysis is necessary. 